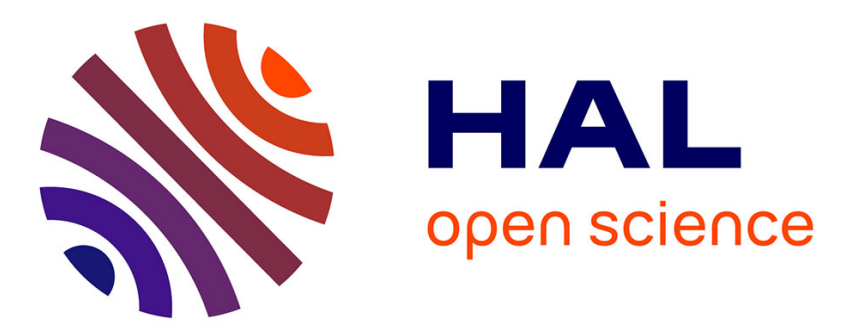

\title{
Removal of hydrogen sulfide in air using cellular concrete waste: Biotic and abiotic filtrations
}

M. Ben Jaber, A. Couvert, A. Amrane, P. Le Cloirec, Eric Dumont

\section{To cite this version:}

M. Ben Jaber, A. Couvert, A. Amrane, P. Le Cloirec, Eric Dumont. Removal of hydrogen sulfide in air using cellular concrete waste: Biotic and abiotic filtrations. Chemical Engineering Journal, 2017, 319, pp.268-278. 10.1016/j.cej.2017.03.014 . hal-01515163

\section{HAL Id: hal-01515163 \\ https://hal-univ-rennes1.archives-ouvertes.fr/hal-01515163}

Submitted on 5 May 2017

HAL is a multi-disciplinary open access archive for the deposit and dissemination of scientific research documents, whether they are published or not. The documents may come from teaching and research institutions in France or abroad, or from public or private research centers.
L'archive ouverte pluridisciplinaire HAL, est destinée au dépôt et à la diffusion de documents scientifiques de niveau recherche, publiés ou non, émanant des établissements d'enseignement et de recherche français ou étrangers, des laboratoires publics ou privés. 


\section{Accepted Manuscript}

Removal of hydrogen sulfide in air using cellular concrete waste: biotic and abiotic filtrations

Mouna Ben Jaber, Annabelle Couvert, Abdeltif Amrane, Pierre Le Cloirec, Eric

Dumont

PII:

S1385-8947(17)30354-6

DOI: http://dx.doi.org/10.1016/j.cej.2017.03.014

Reference:

CEJ 16610

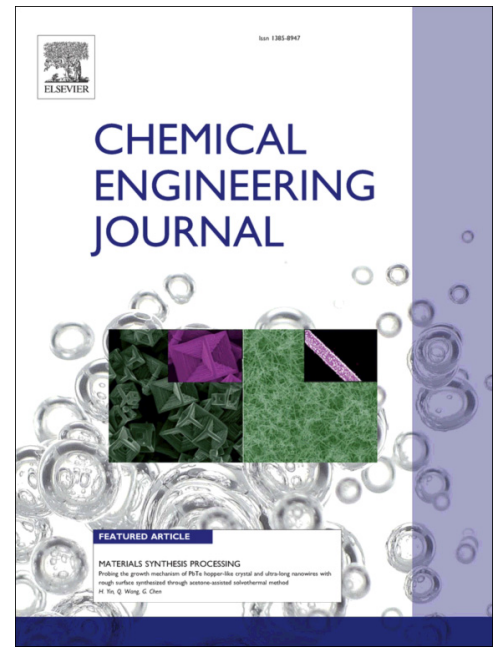

To appear in:

Chemical Engineering Journal

Received Date:

16 January 2017

Revised Date:

3 March 2017

Accepted Date:

6 March 2017

Please cite this article as: M. Ben Jaber, A. Couvert, A. Amrane, P.L. Cloirec, E. Dumont, Removal of hydrogen sulfide in air using cellular concrete waste: biotic and abiotic filtrations, Chemical Engineering Journal (2017), doi: http://dx.doi.org/10.1016/j.cej.2017.03.014

This is a PDF file of an unedited manuscript that has been accepted for publication. As a service to our customers we are providing this early version of the manuscript. The manuscript will undergo copyediting, typesetting, and review of the resulting proof before it is published in its final form. Please note that during the production process errors may be discovered which could affect the content, and all legal disclaimers that apply to the journal pertain. 


\title{
Removal of hydrogen sulfide in air using cellular
}

\section{concrete waste: biotic and abiotic filtrations}

\section{Mouna BEN JABER ${ }^{1}$, Annabelle COUVERT ${ }^{1}$, Abdeltif AMRANE ${ }^{1}$, Pierre LE CLOIREC ${ }^{1}$, Eric DUMONT ${ }^{2(*)}$}

1 Ecole Nationale Supérieure de Chimie de Rennes, CNRS, UMR 6226, 11 Allée de Beaulieu, CS 50837, 35708 Rennes Cedex 7, France

2 UMR CNRS 6144 GEPEA, L’UNAM, École des Mines de Nantes, La Chantrerie, 4 rue Alfred Kastler, B.P. 20722, 44307 Nantes Cedex 3, France

*: Corresponding author

\begin{abstract}
The objective of this study was to investigate the removal of hydrogen sulfide $\left(\mathrm{H}_{2} \mathrm{~S}\right)$ present in air using cellular concrete waste as the packing material. Air filtration was performed under biotic and abiotic conditions. Experiments were carried out in a laboratory-scale PVC column (internal diameter of $300 \mathrm{~mm}$ ) filled with a volume of $70 \mathrm{~L}$ of cellular concrete $(1 \mathrm{~m} \mathrm{height})$. The polluted air flow was generated at $4 \mathrm{~m}^{3} \mathrm{~h}^{-1}$ corresponding to an Empty Bed Residence Time (EBRT) of 63 s. In dry conditions without biomass (abiotic conditions), cellular concrete can be an effective medium for the treatment of $\mathrm{H}_{2} \mathrm{~S}$ in air. For an $\mathrm{H}_{2} \mathrm{~S}$ concentration of $100 \mathrm{ppmv}$, the removal efficiency was around $70 \%$ (Elimination Capacity (EC) of $5.6 \mathrm{~g} \mathrm{~m}^{-}$ ${ }^{3} \mathrm{~h}^{-1}$ ). This finding can be explained by the physicochemical reactions that can take place between $\mathrm{H}_{2} \mathrm{~S}$ and the cellular concrete components (mainly $\mathrm{CaO}, \mathrm{CaCO}_{3}$ and $\mathrm{Fe}_{2} \mathrm{O}_{3}$ ). However, interactions between cellular concrete and $\mathrm{H}_{2} \mathrm{~S}$ are not yet fully understood. Used as a packing material for $\mathrm{H}_{2} \mathrm{~S}$ biofiltration (biotic conditions), cellular concrete waste efficiently
\end{abstract}


treated (Removal Efficiency $=100 \%$ ) high concentrations of $\mathrm{H}_{2} \mathrm{~S}$ (up to $133 \mathrm{ppmv}$ corresponding to an EC of up to $10.5 \mathrm{~g} \mathrm{~m}^{-3} \mathrm{~h}^{-1}$ ). Physicochemical and biological mechanisms explaining $\mathrm{H}_{2} \mathrm{~S}$ removal seem to occur simultaneously in the biofilter. At an EBRT of $63 \mathrm{~s}$, the maximal elimination capacity $\left(\mathrm{EC}_{\max }\right)$ was $17.8 \mathrm{~g} \mathrm{~m}^{-3} \mathrm{~h}^{-1}$. A packed bed of cellular concrete also presents a satisfactory mechanical behavior with low pressure drops.

Keywords: Cellular concrete; Packing material; Biofiltration; $\mathrm{H}_{2} \mathrm{~S}$; Calcium oxide; Iron oxide

\section{Introduction}

Hydrogen sulfide is an odorous, toxic, flammable and corrosive air pollutant. It is a colorless gas with the characteristic foul odor of rotten eggs. $\mathrm{H}_{2} \mathrm{~S}$ can cause death immediately when concentrations are over $500-1000$ ppmv, while exposure to lower concentrations, such as 10 - 500 ppmv, can cause various respiratory symptoms. $\mathrm{H}_{2} \mathrm{~S}$ may also affect the nervous, cardiovascular, and hematological systems. $\mathrm{H}_{2} \mathrm{~S}$ is emitted from various industries, such as petroleum refining, rendering, wastewater treatment, paper manufacturing and food processing. $\mathrm{H}_{2} \mathrm{~S}$ also occurs in volcanic and natural gases. Several processes are available for the treatment of hydrogen sulfide, including absorption [1-5], adsorption [6-11], and membrane separation [12-16]. These methods generally entail high energy, chemical and disposal costs. Biofiltration appears to be a convenient alternative for treating gaseous emissions containing $\mathrm{H}_{2} \mathrm{~S}$. This process uses microorganisms immobilized in the biofilm attached to a packing material. The contaminated gaseous stream flows through the filter bed. $\mathrm{H}_{2} \mathrm{~S}$ is transferred from the gas phase to the biofilm where chemical reactions occur (Eqs. 12). The bacteria most used in the biofiltration of hydrogen sulfide belong to the genus Thiobacillus, which uses $\mathrm{H}_{2} \mathrm{~S}$ as an energy source for growth. 
$\mathrm{H}_{2} \mathrm{~S}+0.5 \mathrm{O}_{2} \rightarrow \mathrm{S}^{0}+\mathrm{H}_{2} \mathrm{O}$

$\mathrm{H}_{2} \mathrm{~S}+2 \mathrm{O}_{2} \rightarrow 2 \mathrm{H}^{+}+\mathrm{SO}_{4}^{2-}$

The selection of the packing material is a key step in a successful biofiltration operation. Organic media, such as compost, peat, and pine bark, are widely used for $\mathrm{H}_{2} \mathrm{~S}$ treatment because they contain nutrients [17-20]. Inorganic media, such as expanded schist, pozzolan and lava, are also used due to their interesting mechanical behavior [21-24]. Currently, a combination of expanded schist and UP20 (a synthetic nutrient material) can be successfully used to treat gas with a high $\mathrm{H}_{2} \mathrm{~S}$ concentration (up to $360 \mathrm{ppmv}$ ). However, if the biofilter is continuously overloaded by $\mathrm{H}_{2} \mathrm{~S}$, sulfate accumulation in the biofilter bed leads to a significant decrease in the process performances related to a $\mathrm{pH}$ decrease $(\mathrm{pH}<1)$. As a result, the watering flow rate of the biofilter must be increased to avoid sulfate accumulation and maintain the $\mathrm{pH}>1$ [21]. In order to limit this fall in $\mathrm{pH}$ due to sulfate production, new packing materials, naturally basic and low-cost, have to be investigated for effective $\mathrm{H}_{2} \mathrm{~S}$ removal. The objective is clearly to find a material that could be used as a $\mathrm{H}_{2} \mathrm{~S}$ scavenger to treat high $\mathrm{H}_{2} \mathrm{~S}$ concentration in air as well as in biogas. In a first approach, the $\mathrm{H}_{2} \mathrm{~S}$ concentrations considered are ranged from 50 to $500 \mathrm{ppmv}$ in order to compare the results obtained with data reported in the literature [17,19,25-27]. One such new material is cellular concrete waste. Cellular concrete is a material whose physical and chemical properties could be useful for the removal of $\mathrm{H}_{2} \mathrm{~S}$. Moreover, the use of waste is an interesting and economic solution for the reduction of air pollution. To the best of our knowledge, this material has never been studied for $\mathrm{H}_{2} \mathrm{~S}$ treatment. Therefore, the objective of this study was to investigate the removal of hydrogen sulfide using cellular concrete by a physical technique and a bioprocess, i.e. biofiltration. The treatment of $\mathrm{H}_{2} \mathrm{~S}$ was first investigated by filtration of the polluted air through a packed bed of cellular concrete in the absence of biomass in dry conditions (i.e. an abiotic filtration). Second, a classic biofiltration was tested using cellular 
concrete as the porous support for biomass attachment. In the latter case, the results could be directly compared with performances obtained using expanded schist in the same operating conditions [21].

\section{Materials and methods}

\subsection{Cellular concrete}

The properties of cellular concrete depend on its microstructure and composition, which are influenced by the type of binder used, methods of pore-formation and curing. The physical, chemical, mechanical and functional characteristics of different cellular concretes are given in the review paper by Narayanan and Ramamurthy [28].

\subsubsection{Composition}

The cellular concrete used in this study is a recycled mineral medium, distributed by the company Florentaise in Nantes, France (http://www.florentaise.com) (Figure 1). Its composition was determined using an Energy Dispersive X-ray Fluorescence Spectrometer (EDX-800HS, Shimadzu Company) (Table 1). Cellular concrete is mainly composed of calcium (Ca) and silicon ( $\mathrm{Si}$ ). A complementary analysis was carried out using X-Ray Diffraction (XRD) (Siemens Brüker D5000). From the XRD peaks (not shown), the following phases were identified: quartz $\left(\mathrm{SiO}_{2}\right)$, calcium carbonate $\left(\mathrm{CaCO}_{3}\right)$, gypsum $\left(\mathrm{CaSO}_{4}, 2 \mathrm{H}_{2} \mathrm{O}\right)$, aluminum oxide $\left(\mathrm{Al}_{2} \mathrm{O}_{3}\right)$, iron oxide $\left(\mathrm{Fe}_{2} \mathrm{O}_{3}\right)$, and calcium silicate hydroxide hydrate $\left(\mathrm{Ca}_{45} \mathrm{Si}_{6} \mathrm{O}_{15}(\mathrm{OH})_{3}, 2 \mathrm{H}_{2} \mathrm{O}\right)$.

\footnotetext{
Figure 1: Picture of cellular concrete particles
} 
Table 1. Composition (\% weight) of cellular concrete and expanded schist as determined by energy dispersive X-ray (the main components are given).

\subsubsection{Properties}

Specific surface area was determined using a Micromeritics ASAP $^{\circledR} 2020$ gas adsorption analyzer. The specific surface area $\left(\mathrm{S}_{\mathrm{BET}}\right)$ was calculated by the Brunauer-Emmett-Teller (BET) method. Internal porosity and apparent density were measured using a mercury porosimeter, Micrometrics autopore IV 9500. The water retention capacity of a material represents the maximum mass of water retained per gram of dry material. The material was immersed for $1 \mathrm{~h}$ in water and then drained for $24 \mathrm{~h}$. The difference in mass was used to calculate its water retention capacity. The $\mathrm{pH}$ of the packing material was measured with a $\mathrm{pH}$ electrode (Consort) connected to a multi-parameter analyzer Consort C561 (measurement accuracy $0.2 \% \pm 1$ digit).

The specific surface area $S_{\mathrm{BET}}$ for cellular concrete was $44 \pm 0.8 \mathrm{~m}^{2} \mathrm{~g}^{-1}$. This value is comparable to that of the synthetic material, Biosorbens ${ }^{\mathrm{TM}}\left(41 \mathrm{~m}^{2} \mathrm{~g}^{-1}\right)$, used by Shareefdeen $e t$ al. [29] for the biofiltration of $\mathrm{H}_{2} \mathrm{~S}$. However, other biofiltration packing materials have low surface areas $\left(<1 \mathrm{~m}^{2} \mathrm{~g}^{-1}\right)$ such as sapwood, pine bark and pozzolan [24]. The density determined for cellular concrete was $547 \pm 5 \mathrm{~kg} \mathrm{~m}^{-3}$. Some biofiltration packing materials have similar densities, such as peanut shells and bagasse $\left(520 \mathrm{~kg} \mathrm{~m}^{-3}\right)$ [30]. Other media have lower densities, such as polypropylene Pall rings $\left(110 \mathrm{~kg} \mathrm{~m}^{-3}\right)$ [31] and wood bark $\left(96 \mathrm{~kg} \mathrm{~m}^{-3}\right)$ [32], whereas others present a high density, such as expanded schist (1248 $\mathrm{kg} \mathrm{m}^{-3}$; Table 3) and pozzolan $\left(1500 \mathrm{~kg} \mathrm{~m}^{-3}\right)$ [25]. The water retention capacity for cellular concrete was $56 \pm$ $2 \%$. This high value can limit the watering rate in the biofilter and avoid compaction of the bed. Moreover, this value is comparable to those obtained for porous lava (47\%) [22], peat (64\%) [33] and UP20 (47\%) [34]. For the pH, cellular concrete was characterized by a value 
of 9. Generally, the $\mathrm{pH}$ of the medium is close to neutrality, with a few exceptions such as peat $(\mathrm{pH}=4.5)[35]$ and pine bark $(\mathrm{pH}=4.5)$ [24]. During $\mathrm{H}_{2} \mathrm{~S}$ treatment by biofiltration, sulfuric acid is produced (Eq. 2) leading to an acidification of the packing material. Having a basic medium can be advantageous to limit the $\mathrm{pH}$ drop in the packed bed biofilter.

Table 2. Physical characteristics of the cellular concrete used in this study. Comparison with expanded schist [21].

\subsection{Experimental set-up}

The laboratory-scale system used for the treatment of $\mathrm{H}_{2} \mathrm{~S}$ by cellular concrete is shown in Figure 2. It consisted of a PVC column with an internal diameter of $300 \mathrm{~mm}$. The column was filled with cellular concrete $(1 \mathrm{~m}$ height; volume $70 \mathrm{~L})$. The air flow was generated using a regulated fan (FMV frequency controller 2107, Leroy Somer, Angouleme, France). It passed through a humidification column (if necessary) with an internal diameter of $200 \mathrm{~mm}$, packed with Hiflow rings (1.50 m height). A stream of $\mathrm{H}_{2} \mathrm{~S}$ (99.7\% purity), controlled by a mass flow controller (Model 5850S, Brooks Instruments, Hatfield, USA), was diluted in the atmospheric air at the outlet of the humidification column. The polluted air was then introduced at the bottom of the biofilter. The $\mathrm{H}_{2} \mathrm{~S}$ concentration was measured along the column, which was equipped with sampling ports located at the inlet and outlet, and at 10, 30, $50,70,90$, and $100 \mathrm{~cm}$ from the bottom of the column (Figure 2). The $\mathrm{H}_{2} \mathrm{~S}$ analyzer was an Onyx 5220 device (measurement accuracy $\pm 1 \%$ ) from the Cosma Environment SA Company (Passy, France).

Leachate samples were taken periodically from the bottom of the column. Their $\mathrm{pH}$ values were measured by a $\mathrm{pH}$ electrode (Consort). Sulfate concentration was determined by the 
turbidimetric method as described in Standard Methods [36] for the examination of water and wastewater.

Figure 2. Schematic diagram of the experimental pilot-scale column used for $\mathrm{H}_{2} \mathrm{~S}$ removal.

\subsection{Operating conditions}

The parameters used in this paper to describe the operating conditions and for the determination of the removal performances were: (i) the inlet Loading Rate $\left(\mathrm{LR}, \mathrm{g} \mathrm{m}^{-3} \mathrm{~h}^{-1}\right)$; (ii) the Elimination Capacity $\left(\mathrm{EC}, \mathrm{g} \mathrm{m}^{-3} \mathrm{~h}^{-1}\right)$; (iii) the Empty Bed Residence Time (EBRT, s); (iv) the Removal Efficiency (RE, \%). All parameters are defined in Table 3. During experiments, the polluted air flow rate was constant at $4 \mathrm{~m}^{3} \mathrm{~h}^{-1}$ corresponding to an EBRT of $63 \mathrm{~s}$.

\section{Table 3. Parameters used in this study.}

\subsubsection{Abiotic experiments}

The treatment of $\mathrm{H}_{2} \mathrm{~S}$ was first investigated by filtration of the polluted air through a packed bed of cellular concrete in the absence of biomass (Table 4). Dry material was used for phases 1 to $10 . \mathrm{H}_{2} \mathrm{~S}$ concentration was sequentially increased from 25 to $250 \mathrm{ppmv}$ (phases 1 to 5 ). Then, for phases 6 to 10 , the $\mathrm{H}_{2} \mathrm{~S}$ concentration level was changed in order to study the ability of the cellular concrete bed to respond to a significant change in the pollutant concentration, i.e. a change in the inlet loading rate (from 6.4 to $40.0 \mathrm{~g} \mathrm{~m}^{-3} \mathrm{~h}^{-1}$ ). 
Table 4. Operating conditions for the filtration of the polluted air through a bed packed with cellular concrete particles in the absence of biomass (air flow rate: $4 \mathrm{~m}^{3} \mathrm{~h}^{-1}$ corresponding to an EBRT of $63 \mathrm{~s}$ ).

\subsubsection{Biofiltration experiments}

The treatment of $\mathrm{H}_{2} \mathrm{~S}$ was also considered by classic biofiltration using cellular concrete as the packing material. The bed (Figure 2) was inoculated with $5 \mathrm{~L}$ of a diluted solution of activated sludge (about $50 \mathrm{mg}$ of dry sewage sludge per liter) from a domestic wastewater treatment plant (Tougas, Nantes, France). The cellular concrete was topped with a layer of the synthetic material UP20 (2 cm corresponding to $1.4 \mathrm{~L})$ in order to provide nutrients for the biomass. UP20 contained urea phosphate $\left(\mathrm{CH}_{4} \mathrm{~N}_{2} \mathrm{O}, \mathrm{H}_{3} \mathrm{PO}_{4}\right)$, calcium carbonate $\left(\mathrm{CaCO}_{3}\right)$ (C/N/P molar ratio: 100/10/ 5) and an organic binder (ELOTEX ST2400; $20 \%$ in mass) from the Elotex Company (Switzerland) [34]. In order to maintain the humidity of the bed material, the biofilter was watered periodically (12 $\mathrm{L}_{\text {day }}{ }^{-1}$, once a day). During biofiltration experiments, an increase in $\mathrm{H}_{2} \mathrm{~S}$ concentration from 40 ppmv to 360 ppmv was applied at a constant EBRT $=63 \mathrm{~s}($ Table 5).

Table 5. Operating conditions for the biofiltration experiments $(\mathrm{EBRT}=63 \mathrm{~s})$. 


\section{Results and discussion}

\subsection{Treatment of $\mathrm{H}_{2} \mathrm{~S}$ using cellular concrete in abiotic conditions}

The effect of increasing the $\mathrm{H}_{2} \mathrm{~S}$ concentration on process performances is highlighted in Figure 3. For phases 1 to 5, the removal efficiency ranged from $90 \%(25 \mathrm{ppmv} ; \mathrm{LR}=2.0 \mathrm{~g}$ $\left.\mathrm{m}^{-3} \mathrm{~h}^{-1}\right)$ to $50 \%\left(250 \mathrm{ppmv} ; \mathrm{LR}=20.0 \mathrm{~g} \mathrm{~m}^{-3} \mathrm{~h}^{-1}\right)$. This finding indicates that a simple filtration of the polluted air through a packed bed of cellular concrete removed a significant proportion of the hydrogen sulfide. Thus, for an $\mathrm{H}_{2} \mathrm{~S}$ concentration of $100 \mathrm{ppmv}$, which represents a level Immediately Dangerous to Life and Health (IDLH) according to the Occupational Safety and Health Administration (OSHA) [37], the removal efficiency was around $70 \%$, corresponding to an elimination capacity of around $5.6 \mathrm{~g} \mathrm{~m}^{-3} \mathrm{~h}^{-1}$. This result means that gas filtration through a packed bed of cellular concrete could be used either to treat the pollution directly in the case of moderately polluted air or as a primary treatment for highly polluted air loaded with $\mathrm{H}_{2} \mathrm{~S}$. The removal efficiencies recorded during phases 1 to 5 were similar to or better than those obtained by biofiltration using natural packing materials, such as sapwood, pine bark or pozzolan $[18,24]$. In order to confirm the ability of cellular concrete to treat the polluted air and respond to a significant change in pollutant load, the $\mathrm{H}_{2} \mathrm{~S}$ concentration was reduced from $250 \mathrm{ppmv}$ to $80 \mathrm{ppmv}$ (phase 6). Surprisingly, the removal efficiency remained constant at around $50 \%$ (Figure 3). A similar procedure was tested again (phases 7 and 8). The increase in the $\mathrm{H}_{2} \mathrm{~S}$ concentration to 250 ppmv led to $\mathrm{RE}=40 \%$ (against $50 \%$ for phase 5) while the return to an $\mathrm{H}_{2} \mathrm{~S}$ concentration of 80 ppmv led to the removal efficiency of $50 \%$ being recovered. Such results revealed that reactions occurred between the cellular concrete and $\mathrm{H}_{2} \mathrm{~S}$, but they could not be strictly related to the change in the loading rate. Two significant increases in $\mathrm{H}_{2} \mathrm{~S}$ concentration were then applied (phases 9 and 10). Whereas a significant drop in the removal efficiency could be expected, RE remained 
surprisingly constant at around $30 \%$. As a result, for the last phase in dry conditions corresponding to an $\mathrm{H}_{2} \mathrm{~S}$ concentration of $500 \mathrm{ppmv}$, the elimination capacity was $12 \mathrm{~g} \mathrm{~m}^{-3} \mathrm{~h}^{-}$ ${ }^{1}$, which confirms the possible interest of using cellular concrete waste as a primary treatment for $\mathrm{H}_{2} \mathrm{~S}$ removal.

Figure 3. Removal efficiency of $\mathrm{H}_{2} \mathrm{~S}$ by cellular concrete in the absence of biomass $\left(\mathrm{H}_{2} \mathrm{~S}\right.$ concentrations from 25 to $500 \mathrm{ppmv}$; EBRT $=63 \mathrm{~s}$ ).

In the light of the results described in Figure 3, the ability of cellular concrete to remove $\mathrm{H}_{2} \mathrm{~S}$ physically in the absence of biomass had to be explained. Sorption mechanisms and chemical reactions between $\mathrm{H}_{2} \mathrm{~S}$ and the cellular concrete components were considered. Due to its specific surface area $\left(44 \mathrm{~m}^{2} \mathrm{~g}^{-1}\right)$, adsorption tests carried out at laboratory scale indicated that cellular concrete is not a good adsorbent for $\mathrm{H}_{2} \mathrm{~S}$ removal (data not shown). Chemical reactions between $\mathrm{H}_{2} \mathrm{~S}$ and the cellular concrete components are therefore probable. Calculating the mass balance of the $\mathrm{H}_{2} \mathrm{~S}$ pollutant between the column inlet and outlet showed that $0.9 \mathrm{~kg}$ of $\mathrm{H}_{2} \mathrm{~S}$ was captured by the material during the 100 days of operation, which corresponded to $42 \mathrm{~g}$ of $\mathrm{H}_{2} \mathrm{~S}$ per $\mathrm{kg}$ of cellular concrete during this period (i.e. $4.2 \% \mathrm{w} / \mathrm{w}$ ). An analysis of the elemental composition of the material using an EDX fluorescence spectrometer confirmed that the cellular concrete reacted with $\mathrm{H}_{2} \mathrm{~S}$, leading to an increase in the percentage weight of the sulfur component in the medium after treatment (Table 6). Between day 0 and day 100, the amount of sulfur component doubled. Taking the volume of the packing material in the column, the porosity of the bed material and the density of the cellular concrete into account, it can be calculated that the increase in the percentage weight 
of the sulfur component was consistent with the amount of $\mathrm{H}_{2} \mathrm{~S}$ calculated from the mass balance.

Table 6. Influence of $\mathrm{H}_{2} \mathrm{~S}$ treatment on cellular concrete composition.

The corrosion of concrete due to the presence of $\mathrm{H}_{2} \mathrm{~S}$ is well documented in the literature, especially in sewer systems [38]. However, there are no data suggesting a single-step reaction between $\mathrm{H}_{2} \mathrm{~S}$ and concrete [39]. There are indications of multi-step reactions leading to the formation of sulfate, gypsum, ettringite and pyrite $[38,40,41]$. Moreover, the interactions between $\mathrm{H}_{2} \mathrm{~S}$ and concrete depend on its composition, which is mainly influenced by the type of binder used. Considering the initial composition of the cellular concrete (Table 1), the removal of $\mathrm{H}_{2} \mathrm{~S}$ can be attributed to the following reactions:

$$
\begin{aligned}
& \mathrm{Fe}_{2} \mathrm{O}_{3}+2 \mathrm{H}_{2} \mathrm{~S}+\mathrm{H}_{2} \rightarrow 2 \mathrm{FeS}+3 \mathrm{H}_{2} \mathrm{O} \\
& \mathrm{FeS}+\mathrm{H}_{2} \mathrm{~S} \rightarrow \mathrm{FeS}_{2}+\mathrm{H}_{2} \\
& \mathrm{CaCO}_{3}+\mathrm{H}_{2} \mathrm{~S} \rightarrow \mathrm{CaS}+\mathrm{H}_{2} \mathrm{O}+\mathrm{CO}_{2} \\
& \mathrm{CaO}+\mathrm{H}_{2} \mathrm{~S} \rightarrow \mathrm{CaS}+\mathrm{H}_{2} \mathrm{O} \\
& \mathrm{CaS}+2 \mathrm{CO}_{2}+2 \mathrm{H}_{2} \mathrm{O} \rightarrow \mathrm{CaSO}_{4}, 2 \mathrm{H}_{2} \mathrm{O}+2 \mathrm{C}
\end{aligned}
$$

The influence of iron was investigated because the addition of iron salts is widely used to control $\mathrm{H}_{2} \mathrm{~S}$ emissions in sewer systems [38] and several materials containing iron oxide, like sewage sludge, red mud, bottom ashes or steel slags, have been identified as possible iron sponges for $\mathrm{H}_{2} \mathrm{~S}$ removal [42]. An analysis by X-ray diffraction (XRD) was carried out before and after treatment. The appearance of two new phases (iron (II) sulfide (FeS) and $\mathrm{FeS}_{2}$ (pyrite)) on the material after treatment was evidenced, confirming chemical reactions between iron and $\mathrm{H}_{2} \mathrm{~S}$ (Eqs. 3-4). A black precipitate of FeS formed on the cellular concrete 
bed according to Eq. (3). However, the rate of $\mathrm{FeS}_{2}$ formation is slow relative to the rate of dissociation of FeS [43]. Thus, FeS acts as a continuous source for pyrite formation (Eq. 4). These results are similar to those found by Sahu et al. [43] who reported the formation of $\mathrm{FeS}_{2}$ and $\mathrm{FeS}$ during the treatment of $\mathrm{H}_{2} \mathrm{~S}$ using red mud. If the ability of cellular concrete to remove $\mathrm{H}_{2} \mathrm{~S}$ was mainly due to the presence of iron and taking into account the initial amount of $\mathrm{Fe}_{2} \mathrm{O}_{3}$ in the cellular concrete $(1.3 \%$ in weight; Table 1$)$, it can be calculated that the amount of $\mathrm{H}_{2} \mathrm{~S}$ that could be treated by the whole packed bed is around $0.25 \mathrm{~kg}$, i.e. around a quarter of the amount of $\mathrm{H}_{2} \mathrm{~S}$ removed from the air. In other words, even if the total amount of iron present in the packed bed probably reacted with $\mathrm{H}_{2} \mathrm{~S}$, other reactions (Eq. 5-7) must be considered inside the packing material to satisfy the mass balance of the $\mathrm{H}_{2} \mathrm{~S}$ pollutant between the column inlet and outlet. It should be noted that the possible production of $\mathrm{SO}_{2}$ due to $\mathrm{H}_{2} \mathrm{~S}$ oxidation was taken into consideration in the mass balance of $\mathrm{H}_{2} \mathrm{~S}$. It is also possible that cellular concrete acts as an iron sponge, allowing the regeneration of iron and the production of elemental sulfur $S^{0}$. The use of iron oxide for gas desulfurization is a wellknown technology. The hydrated iron oxide reacts with $\mathrm{H}_{2} \mathrm{~S}$ forming iron sulfide, thus removing $\mathrm{H}_{2} \mathrm{~S}$ from the gas [44]. Commercial products, such as SulfaMaster ${ }^{\mathrm{TM}}$, Sulfur-Rite ${ }^{\mathrm{TM}}$, Media-G2 ${ }^{\mathrm{TM}}$ and SulfaTreat ${ }^{\mathrm{TM}}$, are major iron sponge systems in which iron oxides are coated onto different supports [45]. Iron oxides can remove $\mathrm{H}_{2} \mathrm{~S}$ by forming insoluble iron sulfides, which can be regenerated by oxidation with air to give elemental sulfur:

$\mathrm{Fe}_{2} \mathrm{O}_{3}+3 \mathrm{H}_{2} \mathrm{~S} \rightarrow \mathrm{Fe}_{2} \mathrm{~S}_{3}+3 \mathrm{H}_{2} \mathrm{O}$

$\mathrm{Fe}_{2} \mathrm{~S}_{3}+3 / 2 \mathrm{O}_{2} \rightarrow \mathrm{Fe}_{2} \mathrm{O}_{3}+3 \mathrm{~S}^{0}$

In such conditions, the packed bed can become clogged by the accumulation of elemental sulfur. However, the regeneration of iron oxide according to Eq. (9) was not evidenced and remains to be demonstrated. 
The conversion of concrete to gypsum and ettringite could also explain the ability of this material to remove $\mathrm{H}_{2} \mathrm{~S}$. According to Eqs. (5-6), calcium carbonate $\left(\mathrm{CaCO}_{3}\right)$ and calcium oxide $(\mathrm{CaO})$ can also react with $\mathrm{H}_{2} \mathrm{~S}$ to form calcium sulfide (CaS) while according to Eq. (7), calcium sulfide could lead to the production of calcium sulfate (gypsum). The calcium sulfate formed can subsequently react, usually via the formation of monosulfoaluminate, to form ettringite [46]. Ettringite is known to be an expansive material that can cause the disintegration of concrete [39]. In the present case, this potential disintegration is not a problem because the purpose of the study is to use cellular concrete waste for gas treatment. Besides, as cellular concrete is mainly composed of calcium oxide, one can assume that large amounts of $\mathrm{H}_{2} \mathrm{~S}$ will be removed before its complete destruction. To date, and although interactions between cellular concrete and $\mathrm{H}_{2} \mathrm{~S}$ are not fully understood, it can be considered that each gram of the cellular concrete used in this study could remove at least $42 \mathrm{mg}$ of $\mathrm{H}_{2} \mathrm{~S}$. Such a finding will be useful to design a column filled with cellular concrete for the treatment of gas polluted by $\mathrm{H}_{2} \mathrm{~S}$. For this purpose, further investigations will be needed to study the behavior of cellular concrete in order to treat $\mathrm{H}_{2} \mathrm{~S}$ in abiotic conditions over a long period.

\subsection{Biofiltration of $\mathrm{H}_{2} \mathrm{~S}$ using cellular concrete as the packing material}

As cellular concrete can remove $\mathrm{H}_{2} \mathrm{~S}$ in abiotic conditions, it can be expected to be an effective support for biofiltration. To check this assumption, the column was inoculated with $5 \mathrm{~L}$ of a diluted solution of activated sludge from a domestic wastewater treatment plant (Tougas, Nantes, France). Consequently, the cellular concrete was not changed between the abiotic and biotic experiments.

\subsubsection{Effect of increasing concentrations on $\mathrm{H}_{2} \mathrm{~S}$ removal}

The influence of an increasing concentration of $\mathrm{H}_{2} \mathrm{~S}$ on the performances of the process is 
shown in Figure 4. Hydrogen sulfide was totally eliminated from the $5^{\text {th }}$ day. A high removal efficiency of $\mathrm{H}_{2} \mathrm{~S}$ (> $99 \%$ ) was observed for concentrations up to $133 \mathrm{ppmv}$. The performances of the process started to decrease from the $43^{\text {rd }}$ day, and this decrease was clearly highlighted from the $60^{\text {th }}$ day when the $\mathrm{H}_{2} \mathrm{~S}$ concentration increased from 250 to 360 ppmv (LR from 20.0 to $28.8 \mathrm{~g} \mathrm{~m}^{-3} \mathrm{~h}^{-1}$ ). For an EBRT of $63 \mathrm{~s}$, the maximal elimination capacity $\left(\mathrm{EC}_{\mathrm{max}}\right)$ obtained with cellular concrete was $17.8 \mathrm{~g} \mathrm{~m}^{-3} \mathrm{~h}^{-1}$. This value is higher than some data reported with other packing materials used for $\mathrm{H}_{2} \mathrm{~S}$ biofiltration. For instance, at an EBRT of $57 \mathrm{~s}$, a maximal elimination capacity of $8 \mathrm{~g} \mathrm{~m}^{-3} \mathrm{~h}^{-1}$ was achieved in a biofilter filled with sapwood [24]. At EBRT $=51 \mathrm{~s}$, an $\mathrm{EC}_{\max }$ of $8 \mathrm{~g} \mathrm{~m}^{-3} \mathrm{~h}^{-1}$ was obtained with Pall rings by Kim et al. [47]. At an EBRT of $30 \mathrm{~s}$, Shareefdeen et al. did not exceed an $\mathrm{EC}_{\max }$ of $8 \mathrm{~g} \mathrm{~m}^{-3} \mathrm{~h}^{-1}$ using a synthetic medium BIOSORBENS ${ }^{\mathrm{TM}}$ as packing material [29]. The comparison with recent biofiltration results reported in the literature at an EBRT close to $63 \mathrm{~s}$ (Table 7) indicates that the removal performances of cellular concrete, although less than those of packing materials such as peat or polyurethane foam, are satisfactory. As a result, cellular concrete waste could be an effective and cheap material for the treatment of gas polluted by $\mathrm{H}_{2} \mathrm{~S}$, especially as the mechanical behavior of the packed bed is suitable as shown below.

Table 7. Examples of recent biofiltration results reported in the literature on the treatment of gas polluted by $\mathrm{H}_{2} \mathrm{~S}$ at an EBRT close to $63 \mathrm{~s}$.

Increasing $\mathrm{H}_{2} \mathrm{~S}$ concentrations led to a decrease in $\mathrm{pH}$ (Figure 4). This can be explained by the accumulation of sulfuric acid as a by-product of the biological oxidation of $\mathrm{H}_{2} \mathrm{~S}$ (Eq. 2). However, even for a high $\mathrm{H}_{2} \mathrm{~S}$ concentration (360 ppmv), the $\mathrm{pH}$ remained greater than 2, whereas the use of expanded schist as the packing material to remove the same $\mathrm{H}_{2} \mathrm{~S}$ 
concentration involved a decrease in $\mathrm{pH}$ to values lower than 1 , leading to a significant fall in the biofilter performances [21]. The initial $\mathrm{pH}$ of cellular concrete $(\mathrm{pH}=9)$ highlights the potential positive effect of this new medium as a packing material for $\mathrm{H}_{2} \mathrm{~S}$ biofiltration.

Figure 4. Removal efficiency of $\mathrm{H}_{2} \mathrm{~S}$ and $\mathrm{pH}$ changes in a biofilter packed with cellular concrete (concentrations of $\mathrm{H}_{2} \mathrm{~S}$ from 40 to $360 \mathrm{ppmv}$; $\mathrm{EBRT}=63 \mathrm{~s}$ ).

Figure 5 shows a picture of the column filled with cellular concrete some days after the end of the biofiltration experiment. One can observe that the column was stratified into two different layers. At the bottom, in a layer of around $20 \mathrm{~cm}$, the cellular concrete kept its original color but a slight orange color also appeared, whereas above, the whole packing material became black. Such coloration underlines the probable presence of ferric oxide $\mathrm{Fe}^{3+}$ and iron (II) sulfide FeS. The presence of $\mathrm{Fe}^{3+}$ can be related to the original composition of the cellular concrete (presence of $\mathrm{Fe}_{2} \mathrm{O}_{3}$. Table 1) and the regeneration of $\mathrm{Fe}^{3+}$ in the biofilter can be explained by the following reactions:

$\mathrm{H}_{2} \mathrm{~S}+2 \mathrm{Fe}^{3+}+2 \mathrm{OH}^{-} \rightarrow \mathrm{S}^{0}+2 \mathrm{Fe}^{2+}+2 \mathrm{H}_{2} \mathrm{O}$

$2 \mathrm{Fe}^{2+}+\mathrm{H}_{2} \mathrm{O}+0.5 \mathrm{O}_{2} \rightarrow 2 \mathrm{Fe}^{3+}+2 \mathrm{OH}^{-}$

According to Eq. (10), $\mathrm{Fe}^{3+}$ reacts with $\mathrm{H}_{2} \mathrm{~S}$ to form elemental sulfur. Then, the $\mathrm{Fe}^{2+}$ produced can be converted into $\mathrm{Fe}^{3+}$ by oxidation with air (Eq. 11). $\mathrm{Fe}^{2+}$ can also be biologically oxidized into $\mathrm{Fe}^{3+}$ using Thiobacillus ferrooxidans. According to Pagella and De Faveri [48], the optimum $\mathrm{pH}$ for the growth of $T$. ferrooxidans is around 2.2, which corresponds to the $\mathrm{pH}$ values recorded at the end of the experiment (Figure 4). At these low $\mathrm{pH}$ values, ferric ion precipitation is avoided. It should be noted that the combined action of a chemical reaction 
step (Eq. 10) and a biological oxidation step exploiting the ability of T. ferrooxidans was considered by Pagella and De Faveri [48] for $\mathrm{H}_{2} \mathrm{~S}$ gas treatment using two distinct columns. This coupled process was first studied under the name of BIO-SR [49] and is close to the commercial SulFerox ${ }^{\circledR}$ process (a Shell Iron Redox process), in which $\mathrm{Fe}^{2+}$ is converted to $\mathrm{Fe}^{3+}$ by oxidation with air. It is interesting to note that, in the presence of biomass, cellular concrete can probably regenerate ferric ion. Finally, the stratification shows that different removal mechanisms (physicochemical and biological) occurred simultaneously in the biofilter. The change in $\mathrm{pH}$ along the height of the column could explain this stratification. Further experiments are necessary to confirm this interpretation.

Figure 5. Picture of the column filled with cellular concrete at the end of the biofiltration experiment.

\subsubsection{Effect of sulfate accumulation on $\mathrm{H}_{2} \mathrm{~S}$ removal}

Sulfuric acid is produced during $\mathrm{H}_{2} \mathrm{~S}$ treatment by biofiltration (Eq. 2). Figure 6 illustrates the influence of sulfate accumulation on the performances of the process. For a sulfate concentration lower than $21 \mathrm{mg}_{\mathrm{S}-\text { sulfate }} / \mathrm{g}_{\text {dry medium }}, \mathrm{H}_{2} \mathrm{~S}$ was completely removed in the biofilter. These results suggest that a sulfate content of around $21 \mathrm{mg} \mathrm{S}-\mathrm{SO}_{4}{ }^{2-} / \mathrm{g}$ is a critical level for the removal of the pollutant. Above this concentration, the removal efficiency decreased. Thus, a significant drop in the removal efficiency, up to $60 \%$, was observed for a concentration of $360 \mathrm{ppmv}$ corresponding to a sulfate concentration of $30 \mathrm{mg}_{\mathrm{S}-\text { sulfate }} / \mathrm{g}_{\text {dry medium }}$ (Figure 6). Such a decrease could be due to a drop in the microbial activity in relation to a biomass inhibition as well as an $\mathrm{H}_{2} \mathrm{~S}$ mass transfer limitation related to the low $\mathrm{pH}$. Therefore, to maintain a high $\mathrm{H}_{2} \mathrm{~S}$ removal efficiency, it is preferable to work at sulfate concentrations lower than $21 \mathrm{mg}_{\mathrm{S}}$ sulfate $/ g_{\text {dry medium. }}$ This critical value is close to that found by Yang and Allen [20] (25 $\mathrm{mg}_{\mathrm{S}-}$ 
sulfate $\left./ \mathrm{g}_{\text {dry medium }}\right)$ and greater than those found for expanded schist (12 $\left.\mathrm{mg}_{\mathrm{S} \text {-sulfate }} / \mathrm{g}_{\text {dry medium }}\right)$ [21] and compost (12 $\mathrm{mg}_{\mathrm{S}-\text { sulfate }} / \mathrm{g}_{\text {dry medium }}$ ) [50]. To avoid sulfate accumulation in the biofilter, Ramirez-Saenz et al.[51] suggested a periodical recirculation of water in the packed bed to limit the concentration to about $8 \mathrm{mg}_{\mathrm{S} \text {-sulfate }} / \mathrm{g}_{\text {dry medium }}$.

Figure 6. Effect of sulfate accumulation on $\mathrm{H}_{2} \mathrm{~S}$ degradation.

\subsubsection{Pressure drops}

The pressure drops $(\Delta \mathrm{P})$ were measured between the ports located at 10 and $100 \mathrm{~cm}$ from the bottom of the biofilter. Pressure drops in biofilters depend mainly on the superficial gas velocity and particle size [52]. At the beginning of the operation, $\Delta \mathrm{P}$ varied between $2 \mathrm{~Pa} \mathrm{~m}^{-1}$ and $62 \mathrm{~Pa} \mathrm{~m}^{-1}$ for gas velocities varying between 56 and $565 \mathrm{~m} \mathrm{~h}^{-1}$ (Figure 7). After 110 days of operation, the pressure drops slightly increased, to reach values between 2 and $74 \mathrm{~Pa} \mathrm{~m}^{-1}$ for the same range of gas velocities. This increase in pressure drop (around $20 \%$ ) during $\mathrm{H}_{2} \mathrm{~S}$ biofiltration can be explained by: (i) the growth of the biofilm; (ii) a possible deposit of elemental sulfur [52-54]; and (iii) a possible formation of gypsum and ettringite (as described in Section 3.1) leading to a degradation of the cellular concrete. In this case, monitoring the $\Delta \mathrm{P}$ change over a long period will give useful information about the change in the mechanical behavior of the packed bed. Nonetheless, it should be highlighted that these $\Delta \mathrm{P}$ values are mostly lower than those found using other packing materials in different studies, which confirms the interest of using cellular concrete for biofiltration. For instance, using pine bark, $\Delta \mathrm{P}$ varied from 15 to $370 \mathrm{~Pa} \mathrm{~m}^{-1}$ at gas velocities varying between 65 and $520 \mathrm{~m} \mathrm{~h}^{-1}$ [25] while for pig manure and sawdust, Elias et al. [54] measured pressure drops between 15 and $460 \mathrm{~Pa} \mathrm{~m}^{-1}$ at gas velocities ranging between 100 and $200 \mathrm{~m} \mathrm{~h}^{-1}$. Moreover, the $\Delta \mathrm{P}$ values 
recorded for the cellular concrete bed are even lower than those found using expanded schist whose mechanical behavior has been identified as excellent for long operation periods (no attrition, no bed compaction) [21]. In fact, for the same range of gas velocities, $\Delta \mathrm{P}$ varied from 4 to $105 \mathrm{~Pa} \mathrm{~m}^{-1}$ (Figure 7), namely $40 \%$ more for a gas velocity of $565 \mathrm{~m} \mathrm{~h}^{-1}$.

Figure 7. Pressure drop measurements in the biofilter for gas velocities varying between 56 and $565 \mathrm{~m}$ $\mathrm{h}^{-1}$ (symbols: experimental data; dashed line: Ergun's model [55]). Comparison with data recorded in the same biofilter filled with expanded schist [21].

\subsubsection{Comparative study: cellular concrete versus expanded schist particles}

The comparison between cellular concrete and expanded schist particles is useful because the latter is recognized as an excellent material for $\mathrm{H}_{2} \mathrm{~S}$ removal in terms of removal efficiency and mechanical behavior [23,26]. As indicated above, the pressure drops in the biofilter filled with cellular concrete were lower than those obtained with expanded schist during 110 days of operation at a gas velocity of $565 \mathrm{~m} \mathrm{~h}^{-1}$ (Figure 7). Nonetheless, this interesting finding remains to be confirmed by studying the behavior of cellular concrete over a long period $(>1$ year in operating conditions). By comparing the removal efficiencies of $\mathrm{H}_{2} \mathrm{~S}$ obtained by cellular concrete to those reported in Ben Jaber et al. [21] using expanded schist, one can observe that expanded schist showed better performances (Figure 8). Although both materials are efficient for concentrations lower than $133 \mathrm{ppmv}\left(\mathrm{LR}=10.6 \mathrm{~g} \mathrm{~m}^{-3} \mathrm{~h}^{-1}\right)$, differences can be observed for concentrations higher than $250 \mathrm{ppmv}$ (corresponding to $\mathrm{LR}>20.0 \mathrm{~g} \mathrm{~m}^{-3} \mathrm{~h}^{-1}$ ). For a loading rate of $28.8 \mathrm{~g} \mathrm{~m}^{-3} \mathrm{~h}^{-1}$ (360 $\mathrm{ppmv}$ ), the removal efficiencies obtained for expanded schist and cellular concrete were $87 \%$ and $63 \%$, respectively (Figure 8). The physical 
characteristics of the two materials given in Table 1 could explain this difference. For example, the amount of iron oxide $\mathrm{Fe}_{2} \mathrm{O}_{3}$ in expanded schist is ten times higher than in cellular concrete. Moreover, the amount of calcium oxide $\mathrm{CaO}$ in expanded schist is very low whereas it is a major component of cellular concrete. Assuming that the overall $\mathrm{H}_{2} \mathrm{~S}$ removal was due to both a physical removal caused by the presence of iron oxide and a biodegradation by the biomass, expanded schist should have better properties for $\mathrm{H}_{2} \mathrm{~S}$ treatment than cellular concrete. A packed bed of expanded schist was previously tested for $\mathrm{H}_{2} \mathrm{~S}$ removal in abiotic conditions; the results are extensively described in Dumont et al. [53]. Removal efficiencies from 30 to $50 \%$ were recorded. However, the experiments were not carried out in dry conditions. Moreover, the EBRTs applied (14 to 35 s) were significantly lower than that used in the present study, which prevents a direct comparison. As a result, further experiments need to be carried out to evaluate and compare the performances of both packing materials to remove $\mathrm{H}_{2} \mathrm{~S}$ without biomass in dry conditions. Such an investigation should provide valuable information about the possible mechanisms of $\mathrm{H}_{2} \mathrm{~S}$ removal due to the presence of calcium and iron in both materials, respectively.

Figure 8. Comparison of the removal efficiencies of $\mathrm{H}_{2} \mathrm{~S}$ using cellular concrete and expanded schist as packing materials $(\mathrm{EBRT}=63 \mathrm{~s} ; \mathrm{pH}>1)$.

\section{Conclusion}

The removal of $\mathrm{H}_{2} \mathrm{~S}$ by cellular concrete waste as a new packing material was evaluated. At a constant EBRT of $63 \mathrm{~s}$, the results are promising in terms of removal efficiency and pressure drops. This packing material thus presents several advantages, summarized below. 
In dry conditions without biomass, cellular concrete can be an effective medium for the treatment of $\mathrm{H}_{2} \mathrm{~S}$ in air. This finding can be explained by chemical reactions that can take place between $\mathrm{H}_{2} \mathrm{~S}, \mathrm{CaO}, \mathrm{CaCO}_{3}$ and $\mathrm{Fe}_{2} \mathrm{O}_{3}$. The large amount of $\mathrm{H}_{2} \mathrm{~S}$ removed suggests that multiple reactions occur in cellular concrete. Gypsum and ettringite are probably formed. Moreover, cellular concrete could act as an iron sponge with iron regeneration. However, the interactions between cellular concrete components and $\mathrm{H}_{2} \mathrm{~S}$ are not yet fully understood. Consequently, further studies are needed to identify the chemical mechanisms between $\mathrm{H}_{2} \mathrm{~S}$ and this material.

Used as a packing material for $\mathrm{H}_{2} \mathrm{~S}$ biofiltration, cellular concrete waste efficiently treated $(\mathrm{RE}=100 \%)$ high concentrations of $\mathrm{H}_{2} \mathrm{~S}$ in air up to 133 ppmv (loading rate up to $10.5 \mathrm{~g} \mathrm{~m}^{-3}$ $\mathrm{h}^{-1}$ ). Physicochemical and biological mechanisms explaining $\mathrm{H}_{2} \mathrm{~S}$ removal seem to occur simultaneously in the biofilter. At an EBRT of $63 \mathrm{~s}$, the maximal elimination capacity $\left(\mathrm{EC}_{\max }\right)$ calculated was $17.8 \mathrm{~g} \mathrm{~m}^{-3} \mathrm{~h}^{-1}$. The packed bed of cellular concrete also presents a satisfactory mechanical behavior with low pressure drops $(30 \%$ lower than those found with expanded schist in the same conditions).

This study is the first experimental evidence that the gaseous pollutant $\mathrm{H}_{2} \mathrm{~S}$ can be removed using cellular concrete waste. Further investigations are necessary (i) to identify the precise chemical and biological mechanisms involved in both abiotic and biofiltration conditions; (ii) to determine the ability of the material to be used over a long period. Investigations could also be performed for the treatment of $\mathrm{H}_{2} \mathrm{~S}$ in biogas with high values of EBRT.

\section{Acknowledgement}


The authors would like to thank Franck ROUXEL and the TC-PLASTIC Company for their

financial support.

\section{References}

[1] P.J.G. Huttenhuis, N.J. Agrawal, J.A. Hogendoorn, G.F. Versteeg, Gas solubility of H2S and CO2 in aqueous solutions of $\mathrm{N}$-methyldiethanolamine, Journal of Petroleum Science and Engineering. 55 (2007) 122-134. doi:10.1016/j.petrol.2006.04.018.

[2] M.A. Pacheco, G.T. Rochelle, Rate-Based Modeling of Reactive Absorption of $\mathrm{CO} 2$ and H2S into Aqueous Methyldiethanolamine, Ind. Eng. Chem. Res. 37 (1998) 4107-4117.

doi:10.1021/ie980123g.

[3] N. Tippayawong, P. Thanompongchart, Biogas Quality Upgrade by Simultaneous Removal of CO2 and H2S in a Packed Column Reactor, ResearchGate. 35 (2010) 4531-4535. doi:10.1016/j.energy.2010.04.014.

[4] M. Taheri, A. Mohebbi, H. Hashemipour, A.M. Rashidi, Simultaneous absorption of carbon dioxide $(\mathrm{CO} 2)$ and hydrogen sulfide $(\mathrm{H} 2 \mathrm{~S})$ from $\mathrm{CO} 2-\mathrm{H} 2 \mathrm{~S}-\mathrm{CH} 4$ gas mixture using amine-based nanofluids in a wetted wall column, J. Nat. Gas Sci. Eng. 28 (2016) 410-417. doi:10.1016/j.jngse.2015.12.014.

[5] W. Shi, N.S. Siefert, B.D. Morreale, Molecular Simulations of $\mathrm{CO} 2, \mathrm{H}-2, \mathrm{H} 2 \mathrm{O}$, and H2S Gas Absorption into Hydrophobic Poly(dimethylsiloxane) (PDMS) Solvent: Solubility and Surface Tension, J. Phys. Chem. C. 119 (2015) 19253-19265. doi:10.1021/acs.jpcc.5b05806.

[6] T.J. Bandosz, On the Adsorption/Oxidation of Hydrogen Sulfide on Activated Carbons at Ambient Temperatures, Journal of Colloid and Interface Science. 246 (2002) 1-20. doi:10.1006/jcis.2001.7952.

[7] P. Cosoli, M. Ferrone, S. Pricl, M. Fermeglia, Hydrogen sulphide removal from biogas by zeolite adsorption: Part I. GCMC molecular simulations, Chemical Engineering Journal. 145 (2008) 8692. doi:10.1016/j.cej.2008.07.034.

[8] G. Ducom, D. Radu-Tirnoveanu, C. Pascual, B. Benadda, P. Germain, Biogas-municipal solid waste incinerator bottom ash interactions: sulphur compounds removal, J. Hazard. Mater. 166 (2009) 1102-1108. doi:10.1016/j.jhazmat.2008.12.024.

[9] T. Mochizuki, M. Kubota, H. Matsuda, L.F.D. Camacho, Adsorption behaviors of ammonia and hydrogen sulfide on activated carbon prepared from petroleum coke by $\mathrm{KOH}$ chemical activation, Fuel Process. Technol. 144 (2016) 164-169. doi:10.1016/j.fuproc.2015.12.012.

[10] Z. Song, Z. Wei, B. Wang, Z. Luo, S. Xu, W. Zhang, H. Yu, M. Li, Z. Huang, J. Zang, F. Yi, H. Liu, Sensitive Room-Temperature H2S Gas Sensors Employing SnO2 Quantum Wire/Reduced Graphene Oxide Nanocomposites, Chem. Mat. 28 (2016) 1205-1212. doi:10.1021/acs.chemmater.5b04850.

[11] T. Yamamoto, M. Tayakout-Fayolle, C. Geantet, Gas-phase removal of hydrogen sulfide using iron oxyhydroxide at low temperature: Measurement of breakthrough curve and modeling of sulfidation mechanism, Chem. Eng. J. 262 (2015) 702-709. doi:10.1016/j.cej.2014.09.093.

[12] G. Chatterjee, A.A. Houde, S.A. Stern, Poly(ether urethane) and poly(ether urethane urea) membranes with high $\mathrm{H} 2 \mathrm{~S} / \mathrm{CH} 4$ selectivity, Journal of Membrane Science. 135 (1997) 99-106. doi:10.1016/S0376-7388(97)00134-8. 
[13] S.E. Kentish, C.A. Scholes, G.W. Stevens, Carbon dioxide separation through polymeric membrane systems for flue gas applications, Recent Patents on Chemical Engineering. 1 (2008) 52-66.

[14] B. Kraftschik, W.J. Koros, J.R. Johnson, O. Karvan, Dense film polyimide membranes for aggressive sour gas feed separations, J. Membr. Sci. 428 (2013) 608-619. doi:10.1016/j.memsci.2012.10.025.

[15] H. Maghsoudi, M. Soltanieh, Simultaneous separation of $\mathrm{H} 2 \mathrm{~S}$ and $\mathrm{CO} 2$ from $\mathrm{CH} 4$ by a high silica CHA-type zeolite membrane, J. Membr. Sci. 470 (2014) 159-165. doi:10.1016/j.memsci.2014.07.025.

[16] X. Ren, J. Ren, M. Deng, Poly(amide-6-b-ethylene oxide) membranes for sour gas separation, Sep. Purif. Technol. 89 (2012) 1-8. doi:10.1016/j.seppur.2012.01.004.

[17] M. Ben Jaber, B. Anet, A. Amrane, C. Couriol, T. Lendormi, P.L. Cloirec, G. Cogny, R. Fillières, Impact of nutrients supply and $\mathrm{pH}$ changes on the elimination of hydrogen sulfide, dimethyl disulfide and ethanethiol by biofiltration, Chemical Engineering Journal. 258 (2014) 420-426. doi:10.1016/j.cej.2014.07.085.

[18] E. Dumont, F.D.S. Cabral, P. Le Cloirec, Y. Andrès, Biofiltration using peat and a nutritional synthetic packing material: influence of the packing configuration on $\mathrm{H} 2 \mathrm{~S}$ removal, Environmental Technology. 34 (2013) 1123-1129. doi:10.1080/09593330.2012.736691.

[19] P. Oyarzún, F. Arancibia, C. Canales, G.E. Aroca, Biofiltration of high concentration of hydrogen sulphide using Thiobacillus thioparus, Process Biochemistry. 39 (2003) 165-170. doi:10.1016/S0032-9592(03)00050-5.

[20] Y. Yang, E.R. Allen, Biofiltration Control of Hydrogen Sulfide 1. Design and Operational Parameters, Air \& Waste. 44 (1994) 863-868. doi:10.1080/1073161X.1994.10467287.

[21] M. Ben Jaber, A. Couvert, A. Amrane, F. Rouxel, P. Le Cloirec, E. Dumont, Biofiltration of high concentration of $\mathrm{H} 2 \mathrm{~S}$ in waste air under extreme acidic conditions, New Biotechnology. 33 (2016) 136-143. doi:10.1016/j.nbt.2015.09.008.

[22] K.-S. Cho, H.W. Ryu, N.Y. Lee, Biological deodorization of hydrogen sulfide using porous lava as a carrier of Thiobacillus thiooxidans, Journal of Bioscience and Bioengineering. 90 (2000) 25-31. doi:10.1016/S1389-1723(00)80029-8.

[23] A. Courtois, Y. Andrès, É. Dumont, H2S biofiltration using expanded schist as packing material: influence of packed bed configurations at constant EBRT, J. Chem. Technol. Biotechnol. 90 (2015) 50-56. doi:10.1002/jctb.4456.

[24] E. Dumont, Y. Andrès, Evaluation of innovative packing materials for the biodegradation of $\mathrm{H} 2 \mathrm{~S}$ : a comparative study, J. Chem. Technol. Biotechnol. 85 (2010) 429-434. doi:10.1002/jctb.2334.

[25] E. Dumont, Y. Andrès, P. Le Cloirec, F. Gaudin, Evaluation of a new packing material for H2S removed by biofiltration, Biochemical Engineering Journal. 42 (2008) 120-127. doi:10.1016/j.bej.2008.06.012.

[26] A.C. Romero Hernandez, M.S. Rodríguez Susa, Y. Andrès, E. Dumont, Steady- and transientstate $\mathrm{H} 2 \mathrm{~S}$ biofiltration using expanded schist as packing material, New Biotechnology. 30 (2013) 210-218. doi:10.1016/j.nbt.2012.07.003.

[27] Z.M. Shareefdeen, Development of a biofilter media for removal of hydrogen sulphide, Global Nest Journal. 11 (2009) 218-222.

[28] N. Narayanan, K. Ramamurthy, Structure and properties of aerated concrete: a review, Cement and Concrete Composites. 22 (2000) 321-329. doi:10.1016/S0958-9465(00)00016-0.

[29] Z. Shareefdeen, B. Herner, D. Webb, S. Wilson, Hydrogen sulfide (H2S) removal in synthetic media biofilters, Environ. Prog. 22 (2003) 207-213. doi:10.1002/ep.670220319.

[30] E. Ramírez-López, J. Corona-Hernández, L. Dendooven, P. Rangel, F. Thalasso, Characterization of five agricultural by-products as potential biofilter carriers, Bioresource Technology. 88 (2003) 259-263. doi:10.1016/S0960-8524(02)00315-2.

[31] M. Fernández, M. Ramírez, R.M. Pérez, J.M. Gómez, D. Cantero, Hydrogen sulphide removal from biogas by an anoxic biotrickling filter packed with Pall rings, Chemical Engineering Journal. 225 (2013) 456-463. doi:10.1016/j.cej.2013.04.020. 
[32] E. Smet, G. Chasaya, H.V. Langenhove, W. Verstraete, The effect of inoculation and the type of carrier material used on the biofiltration of methyl sulphides, Appl Microbiol Biotechnol. 45 (1996) 293-298. doi:10.1007/s002530050686.

[33] G. Wu, A. Dupuy, A. Leroux, R. Brzezinski, M. Heitz, Peat-Based Toluene Biofiltration: A New Approach to the Control of Nutrients and pH, Environmental Technology. 20 (1999) 367-376. doi:10.1080/09593332008616829.

[34] F. Gaudin, Y. Andres, P. Le Cloirec, Packing material formulation for odorous emission biofiltration, Chemosphere. 70 (2008) 958-966. doi:10.1016/j.chemosphere.2007.08.014.

[35] B. Anet, C. Couriol, T. Lendormi, A. Amrane, P.L. Cloirec, G. Cogny, R. Fillières, Characterization and Selection of Packing Materials for Biofiltration of Rendering Odourous Emissions, Water Air Soil Pollut. 224 (2013) 1-13. doi:10.1007/s11270-013-1622-1.

[36] American Public Health Association, Standard Methods for the Examination of Water and Wastewater, 14th ed., APHA, Washington, DC, 1975.

http://www.sciencedirect.com/science/article/pii/S1385894715015636 (accessed June 15, 2016).

[37] OSHA, hydrogen_sulfide_fact.pdf, (2005). https://www.osha.gov/OshDoc/data_Hurricane_Facts/hydrogen_sulfide_fact.pdf.

[38] L. Zhang, P. De Schryver, B. De Gusseme, W. De Muynck, N. Boon, W. Verstraete, Chemical and biological technologies for hydrogen sulfide emission control in sewer systems: A review, Water Research. 42 (2008) 1-12. doi:10.1016/j.watres.2007.07.013.

[39] L. Zhang, D.A. Dzombak, D.V. Nakles, S.B. Hawthorne, D.J. Miller, B.G. Kutchko, C.L. Lopano, B.R. Strazisar, Characterization of pozzolan-amended wellbore cement exposed to $\mathrm{CO} 2$ and $\mathrm{H} 2 \mathrm{~S}$ gas mixtures under geologic carbon storage conditions, International Journal of Greenhouse Gas Control. 19 (2013) 358-368. doi:10.1016/j.ijggc. 2013.09.004.

[40] N. Jacquemet, J. Pironon, V. Lagneau, J. Saint-Marc, Armouring of well cement in H2S-CO2 saturated brine by calcite coating - Experiments and numerical modelling, Applied Geochemistry. 27 (2012) 782-795. doi:10.1016/j.apgeochem.2011.12.004.

[41] B.G. Kutchko, B.R. Strazisar, S.B. Hawthorne, C.L. Lopano, D.J. Miller, J.A. Hakala, G.D. Guthrie, $\mathrm{H} 2 \mathrm{~S}-\mathrm{CO} 2$ reaction with hydrated Class $\mathrm{H}$ well cement: Acid-gas injection and $\mathrm{CO} 2 \mathrm{Co}-$ sequestration, International Journal of Greenhouse Gas Control. 5 (2011) 880-888. doi:10.1016/j.ijggc.2011.02.008.

[42] L. Sarperi, A. Surbrenat, A. Kerihuel, F. Chazarenc, The use of an industrial by-product as a sorbent to remove $\mathrm{CO} 2$ and $\mathrm{H} 2 \mathrm{~S}$ from biogas, Journal of Environmental Chemical Engineering. 2 (2014) 1207-1213. doi:10.1016/j.jece.2014.05.002.

[43] R.C. Sahu, R. Patel, B.C. Ray, Removal of hydrogen sulfide using red mud at ambient conditions, Fuel Processing Technology. 92 (2011) 1587-1592. doi:10.1016/j.fuproc.2011.04.002.

[44] E. Dillon, Composition and Method for Sweetening Hydrocarbons, WO/1990/007467, 1990. https://patentscope.wipo.int/search/en/detail.jsf?docld=WO1990007467 (accessed November 24, 2016).

[45] P. Cherosky, Y. Li, Hydrogen sulfide removal from biogas by bio-based iron sponge, Biosystems Engineering. 114 (2013) 55-59. doi:10.1016/j.biosystemseng.2012.10.010.

[46] A. Neville, The confused world of sulfate attack on concrete, Cement and Concrete Research. 34 (2004) 1275-1296. doi:10.1016/j.cemconres.2004.04.004.

[47] J.H. Kim, E.R. Rene, H.S. Park, Biological oxidation of hydrogen sulfide under steady and transient state conditions in an immobilized cell biofilter, Bioresource Technology. 99 (2008) 583-588. doi:10.1016/j.biortech.2006.12.028.

[48] C. Pagella, D.M. De Faveri, H2S gas treatment by iron bioprocess, Chemical Engineering Science. 55 (2000) 2185-2194. doi:10.1016/S0009-2509(99)00482-0.

[49] A. Rehmat, J. Yoshizawa, D. Dalrymple, L. Echterhoff, D. Leppin, BIO-SR process for subquality natural gas, in: 1995: pp. 93-102. http://cat.inist.fr/?aModele=afficheN\&cpsidt=3148685 (accessed November 1, 2014). 
[50] J.M. Morgan-Sagastume, A. Noyola, Hydrogen sulfide removal by compost biofiltration: Effect of mixing the filter media on operational factors, Bioresource Technology. 97 (2006) 15461553. doi:10.1016/j.biortech.2005.06.003.

[51] D. Ramírez-Sáenz, P.B. Zarate-Segura, C. Guerrero-Barajas, E.I. García-Peña, H2S and volatile fatty acids elimination by biofiltration: Clean-up process for biogas potential use, Journal of Hazardous Materials. 163 (2009) 1272-1281. doi:10.1016/j.jhazmat.2008.07.129.

[52] E. Dumont, S. Woudberg, J. Van Jaarsveld, Assessment of porosity and biofilm thickness in packed beds using porous media models, Powder Technology. 303 (2016) 76-89. doi:10.1016/j.powtec.2016.08.060.

[53] E. Dumont, L.M. Ayala Guzman, M.S. Rodríguez Susa, Y. Andrès, H2S biofiltration using expanded schist as packing material: performance evaluation and packed-bed tortuosity assessment, J. Chem. Technol. Biotechnol. 87 (2012) 725-731. doi:10.1002/jctb.3713.

[54] A. Elias, A. Barona, A. Arreguy, J. Rios, I. Aranguiz, J. Peñas, Evaluation of a packing material for the biodegradation of H2S and product analysis, Process Biochemistry. 37 (2002) 813-820. doi:10.1016/S0032-9592(01)00287-4.

[55] I.F. Macdonald, M.S. El-Sayed, K. Mow, F.A.L. Dullien, Flow through Porous Media-the Ergun Equation Revisited, Ind. Eng. Chem. Fund. 18 (1979) 199-208. doi:10.1021/i160071a001. 
Table 4. Composition (\% weight) of cellular concrete and expanded schist as determined by energy dispersive $\mathrm{X}$-ray (the main components are given).

\begin{tabular}{|c|c|c|c|c|}
\hline \multicolumn{2}{|c|}{$\begin{array}{c}\text { Elemental composition of } \\
\text { cellular concrete (\%) }\end{array}$} & \multicolumn{3}{|c|}{$\begin{array}{c}\text { Comparison of composition of cellular concrete and } \\
\text { expanded schist }\end{array}$} \\
\cline { 3 - 5 } & & Composition (\%) & Cellular concrete & Expanded schist \\
\hline $\mathbf{C a}$ & 44.8 & $\mathbf{S i O}_{\mathbf{2}}$ & 50.5 & 56.4 \\
\hline $\mathbf{S i}$ & 41.8 & $\mathbf{C a O}$ & 24.6 & 0.9 \\
\hline $\mathbf{S}$ & 6.8 & $\mathbf{S O}_{\mathbf{3}}$ & 19.7 & 1.6 \\
\hline $\mathbf{F e}$ & 2.7 & $\mathbf{A l}_{\mathbf{2}} \mathbf{O}_{\mathbf{3}}$ & 2.2 & 20.5 \\
\hline $\mathbf{A l}$ & 2.0 & $\mathbf{P}_{\mathbf{2}} \mathbf{O}_{\mathbf{5}}$ & 1.4 & 1.6 \\
\hline $\mathbf{P}$ & 1.3 & $\mathbf{F e}_{\mathbf{2}} \mathbf{O}_{\mathbf{3}}$ & 1.3 & 12.4 \\
\hline $\mathbf{K}$ & 0.4 & $\mathbf{K}_{\mathbf{2}} \mathbf{O}$ & 0.2 & 5.0 \\
\hline
\end{tabular}


Table 5. Physical characteristics of the cellular concrete used in this study. Comparison with expanded schist [13].

\begin{tabular}{|c|c|c|}
\hline Physical characteristics & Cellular concrete & Expanded schist \\
\hline Density $\left(\mathrm{kg} \mathrm{m}^{-3}\right)$ & 547 & 1248 \\
\hline Median diameter $(\mathrm{mm})$ & 11 & 12 \\
\hline Specific surface area $\mathrm{S}_{\mathrm{BET}}\left(\mathrm{m}^{2} \mathrm{~g}^{-1}\right)$ & 44 & - \\
\hline Internal porosity (\%) & 64 & 47 \\
\hline Initial $\mathrm{pH}$ & 9 & 7 \\
\hline Water retention capacity (\%) & $56 \%$ & - \\
\hline
\end{tabular}


Table 6. Parameters used in this study.

\begin{tabular}{|c|c|c|}
\hline Parameter & Definition & Nomenclature \\
\hline Loading Rate (LR) & $\operatorname{LR}\left(\mathrm{g} \mathrm{m}^{-3} \mathrm{~h}^{-1}\right)=\frac{\mathrm{Q}}{\mathrm{V}} \mathrm{C}_{\mathrm{G}}^{\mathrm{in}}$ & \multirow{4}{*}{$\begin{array}{c}\mathrm{C}_{\mathrm{G}}^{\text {in }} \text { : inlet concentration }\left(\mathrm{g} \mathrm{m}^{-3}\right) \\
\mathrm{C}_{\mathrm{G}}^{\text {out }} \text { : outlet concentration }\left(\mathrm{g} \mathrm{m}^{-3}\right) \\
\text { Q: gas flow rate }\left(\mathrm{m}^{3} \mathrm{~h}^{-1}\right) \\
\text { V: bed volume }\left(\mathrm{m}^{3}\right)\end{array}$} \\
\hline Elimination Capacity (EC) & $\mathrm{EC}\left(\mathrm{g} \mathrm{m}^{-3} \mathrm{~h}^{-1}\right)=\left(\mathrm{C}_{\mathrm{G}}^{\text {in }}-\mathrm{C}_{\mathrm{G}}^{\text {out }}\right) \frac{\mathrm{Q}}{\mathrm{V}}$ & \\
\hline $\begin{array}{c}\text { Empty Bed Residence Time } \\
\text { (EBRT) }\end{array}$ & $\operatorname{EBRT}(\mathrm{s})=\frac{\mathrm{V}}{\mathrm{Q}}$ & \\
\hline Removal Efficiency (RE) & $\operatorname{RE}(\%)=\frac{\left(C_{G}^{\text {in }}-C_{G}^{\text {out }}\right)}{C_{G}^{\text {in }}} 100$ & \\
\hline
\end{tabular}


Table 4. Operating conditions for the filtration of the polluted air through a bed packed with cellular concrete particles in the absence of biomass (air flow rate: $4 \mathrm{~m}^{3} \mathrm{~h}^{-1}$ corresponding to an EBRT of $63 \mathrm{~s} ;\left[\mathrm{H}_{2} \mathrm{~S}\right]$ concentrations $\pm 1 \% ; \mathrm{LR} \pm 5 \%$ ).

\begin{tabular}{cccc}
\hline Phase & Duration (days) & {$\left[\mathbf{H}_{\mathbf{2}} \mathbf{S}\right](\mathbf{p p m v})$} & $\mathbf{L R}\left(\mathbf{g ~ m}^{\mathbf{- 3}} \mathbf{h}^{\mathbf{- 1}}\right)$ \\
\hline \multicolumn{5}{c}{ Dry conditions } \\
\hline 1 & 13 & 25 & 2.0 \\
3 & 13 & 50 & 4.0 \\
4 & 13 & 100 & 8.0 \\
5 & 12 & 150 & 12.0 \\
6 & 10 & 250 & 20.0 \\
7 & 5 & 80 & 6.4 \\
8 & 8 & 250 & 20.0 \\
9 & 6 & 80 & 6.4 \\
10 & 5 & 350 & 28.0 \\
\hline
\end{tabular}


Table 5. Operating conditions for the biofiltration experiments $\left(E B R T=63 \mathrm{~s} ;\left[\mathrm{H}_{2} \mathrm{~S}\right]\right.$ concentrations $\pm 1 \% ; \mathrm{LR} \pm 5 \%$ )

\begin{tabular}{cccc}
\hline Phase & Duration (days) & {$\left[\mathbf{H}_{\mathbf{2}} \mathbf{S}\right] \mathbf{( p p m v )}$} & $\mathbf{L R}\left(\mathbf{g ~ m}^{-\mathbf{3}} \mathbf{h}^{-\mathbf{1}}\right)$ \\
\hline 1 & 7 & 40 & 3.2 \\
2 & 7 & 60 & 4.8 \\
3 & 13 & 80 & 6.4 \\
4 & 16 & 133 & 10.6 \\
5 & 16 & 250 & 20.0 \\
6 & 15 & 360 & 28.8 \\
\hline
\end{tabular}


Table 6. Influence of $\mathrm{H}_{2} \mathrm{~S}$ treatment on cellular concrete composition.

\begin{tabular}{ccc}
\hline Composition & $\begin{array}{c}\text { Before } \mathrm{H}_{2} \text { S treatment } \\
\text { (\% weight) }\end{array}$ & $\begin{array}{c}\text { After } \mathbf{1 0 0} \text { days of } \mathbf{H}_{2} \text { S treatment } \\
\text { (\% weight) }\end{array}$ \\
\hline $\mathrm{Ca}$ & 44.8 & 42.0 \\
$\mathrm{Si}$ & 41.8 & 36.5 \\
$\mathrm{~S}$ & 6.8 & 15.6 \\
$\mathrm{Fe}$ & 2.7 & 2.5 \\
$\mathrm{Al}$ & 2.0 & 1.6 \\
$\mathrm{P}$ & 1.3 & 1.2 \\
$\mathrm{~K}$ & 0.4 & 0.4 \\
\hline
\end{tabular}


Table 7. Examples of recent biofiltration results reported in the literature on the treatment of gas polluted by $\mathrm{H}_{2} \mathrm{~S}$ at an EBRT close to $63 \mathrm{~s}$.

\begin{tabular}{|c|c|c|c|c|}
\hline Packing material & $\begin{array}{c}\text { EBRT } \\
(\mathbf{s})\end{array}$ & $\begin{array}{c}\text { Elimination } \\
\text { Capacity } \\
\text { EC }\left(\mathrm{g} \mathrm{m}^{-3} \mathbf{h}^{-1}\right) \\
\end{array}$ & $\begin{array}{c}\text { Removal } \\
\text { Efficiency RE } \\
(\%)\end{array}$ & Reference \\
\hline Peat & 60 & 65.9 & 90 & [38] \\
\hline Peat & 57 & 25.5 & 50 & [16] \\
\hline Sugarcane bagasse & 49 & 73 & & [39] \\
\hline Coconut fiber & 49 & 68 & & [39] \\
\hline Pine bark & 57 & 10 & 69 & [22] \\
\hline Sapwood & 57 & 8 & 50 & {$[16]$} \\
\hline $\begin{array}{l}\text { Synthetic medium } \\
\text { (UP20) }\end{array}$ & 57 & 10 & 93 & [22] \\
\hline Peat + UP20 (mixed) & 57 & 25.5 & 80 & [16] \\
\hline $\begin{array}{c}\text { Pozzolan + UP20 } \\
\text { (layers) }\end{array}$ & 57 & 10 & & [22] \\
\hline Polyurethane foam & 80 & 56.6 & 95 & [40] \\
\hline Polyurethane foam & 49 & 66 & & [39] \\
\hline $\begin{array}{c}\text { Biomedium encapsulated } \\
\text { by Na-alginate and } \\
\text { polyvinyl alcohol }\end{array}$ & 51 & 6 & 99 & [37] \\
\hline Cellular concrete & 63 & $\begin{array}{l}10.5 \\
17.8\end{array}$ & $\begin{array}{c}100 \\
63\end{array}$ & This study \\
\hline
\end{tabular}


Figure 2: Picture of cellular concrete particles

Figure 2. Schematic diagram of the experimental pilot-scale column used for $\mathrm{H}_{2} \mathrm{~S}$ removal.

Figure 3. Removal efficiency of $\mathrm{H}_{2} \mathrm{~S}$ by cellular concrete in the absence of biomass $\left(\mathrm{H}_{2} \mathrm{~S}\right.$ concentrations from 25 to 500 ppmv; EBRT $=63 \mathrm{~s}$; RE values $\pm 2 \%$ ).

Figure 4. Removal efficiency of $\mathrm{H}_{2} \mathrm{~S}$ and $\mathrm{pH}$ changes in a biofilter packed with cellular concrete (concentrations of $\mathrm{H}_{2} \mathrm{~S}$ from 40 to 360 ppmv; EBRT $=63 \mathrm{~s}$; RE values $\pm 2 \%$; $\mathrm{pH}$ values \pm 0.2$)$.

Figure 5. Picture of the column filled with cellular concrete at the end of the biofiltration experiment.

Figure 6. Effect of sulfate accumulation on $\mathrm{H}_{2} \mathrm{~S}$ degradation ( $\mathrm{RE}$ values $\pm 2 \%$; $\mathrm{pH}$ values \pm $0.2)$.

Figure 7. Pressure drop measurements in the biofilter for gas velocities varying between 56 and $565 \mathrm{~m} \mathrm{~h}^{-1}$ (symbols: experimental data; dashed line: Ergun's model [48]). Comparison with data recorded in the same biofilter filled with expanded schist [13]. 
Figure 8. Comparison of the removal efficiencies of $\mathrm{H}_{2} \mathrm{~S}$ using cellular concrete and expanded schist as packing materials $($ EBRT $=63 \mathrm{~s} ; \mathrm{pH}>1)$. 

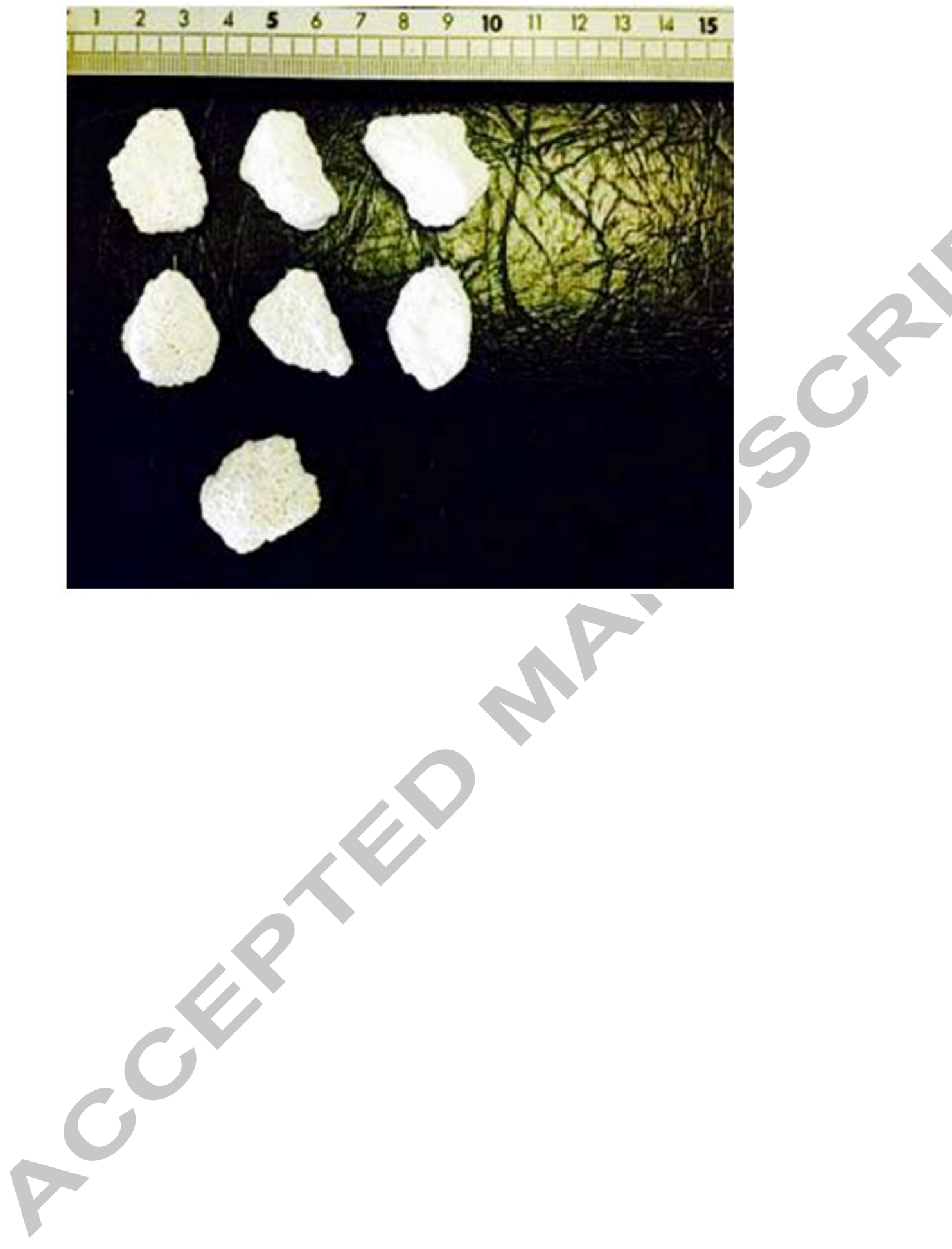


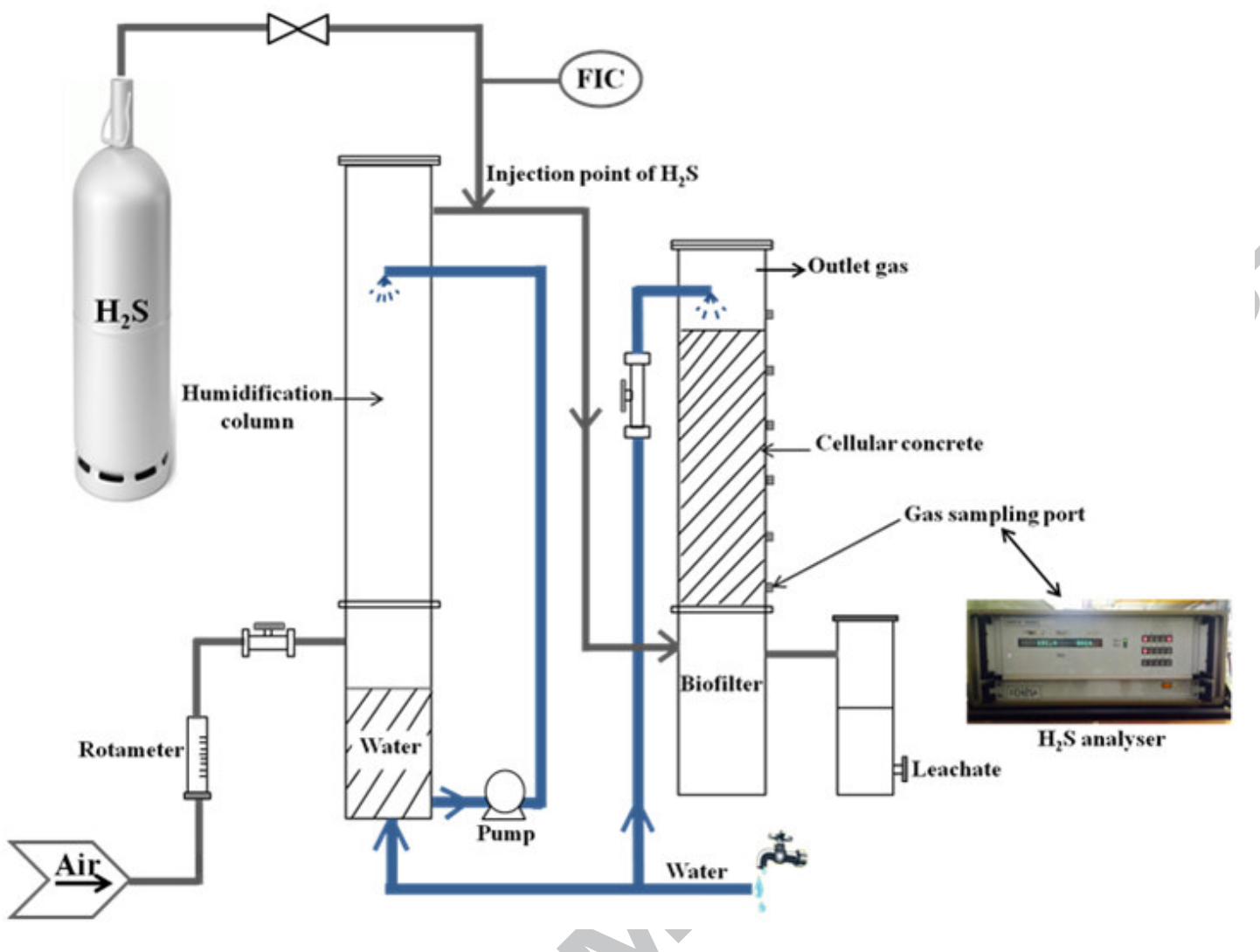




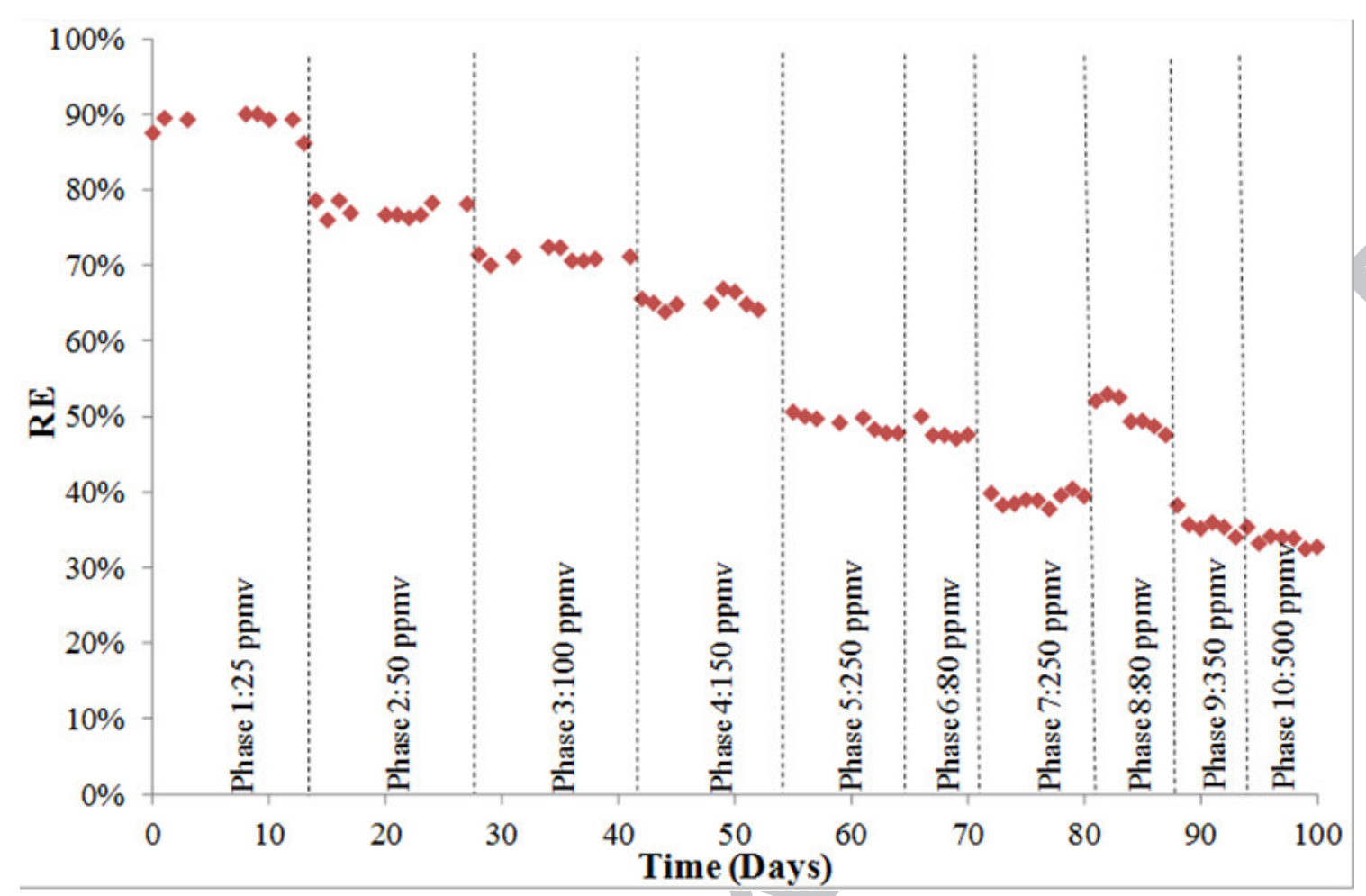




\section{ACCEPTED MANUSCRIPT}

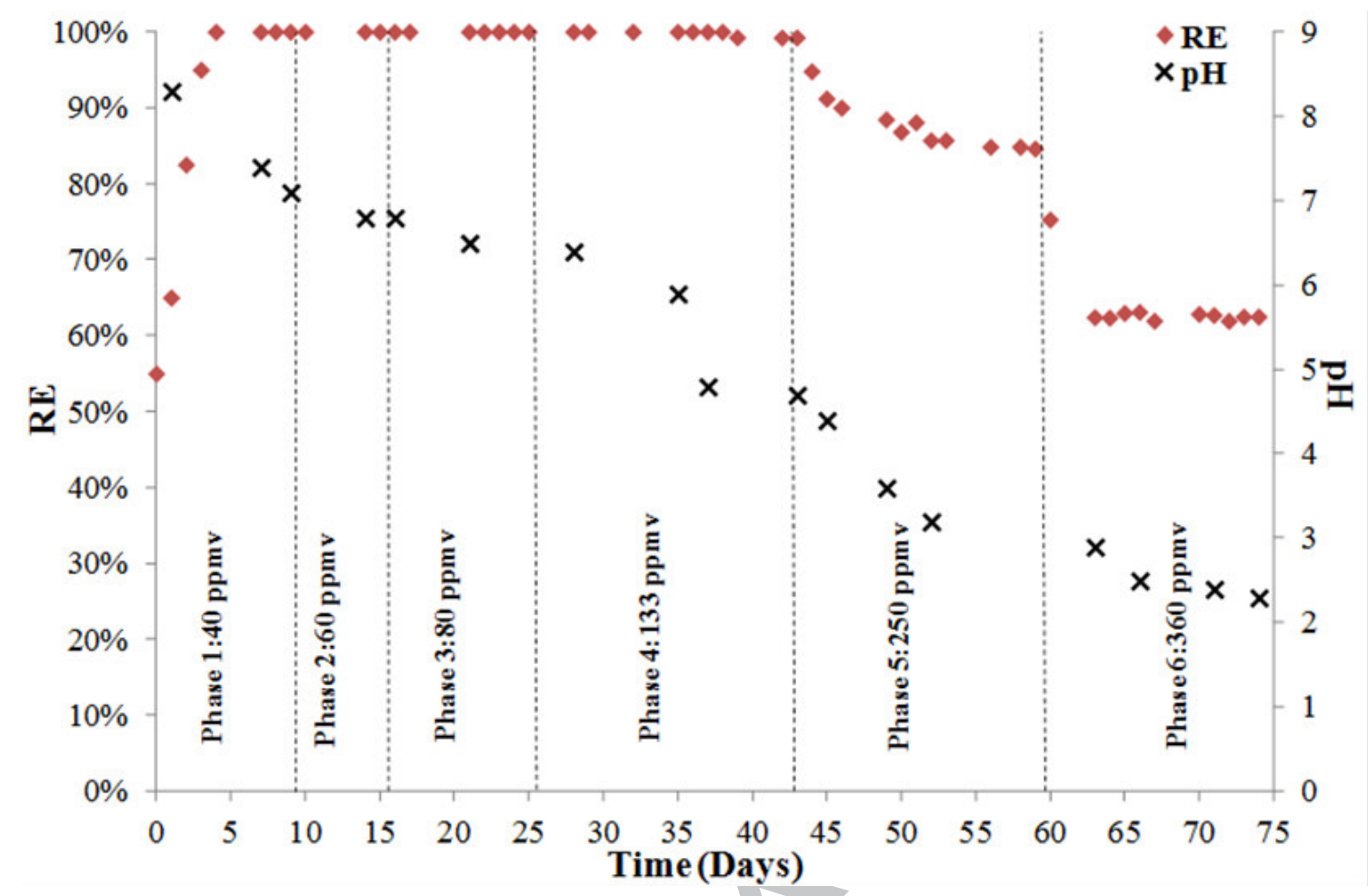



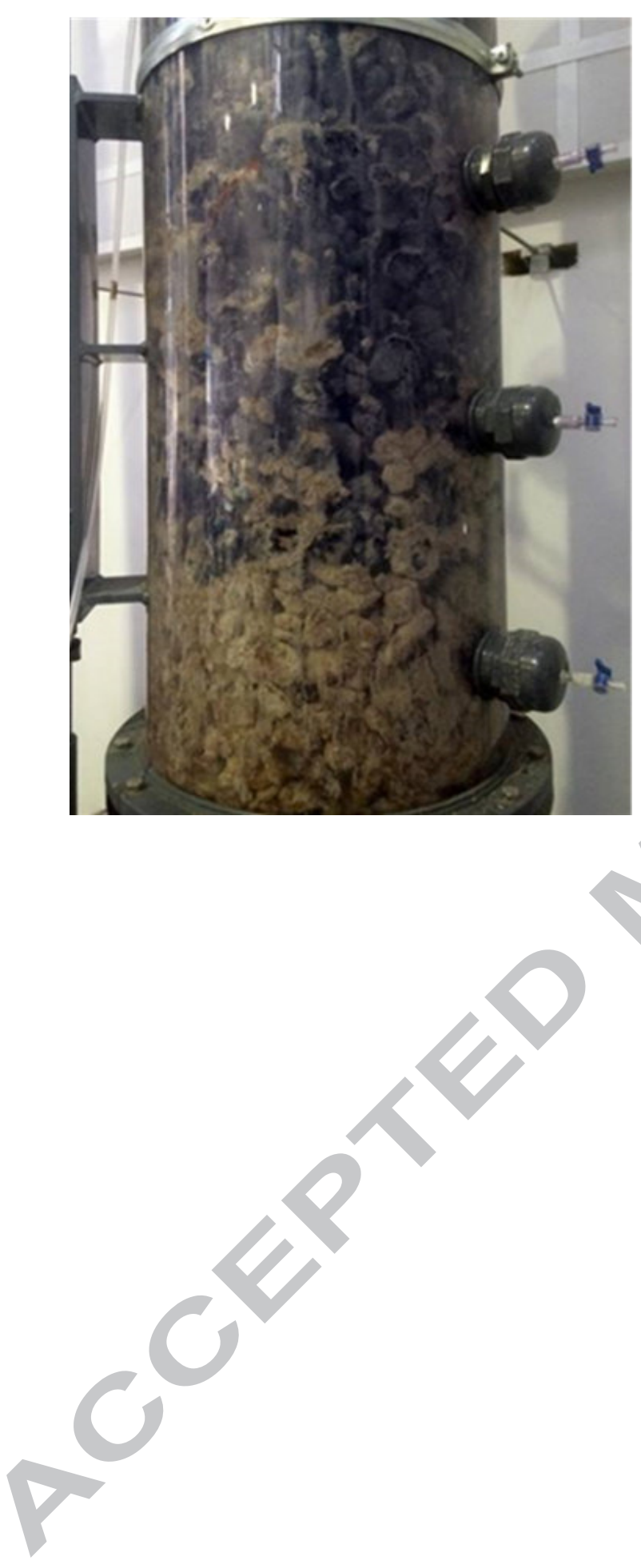


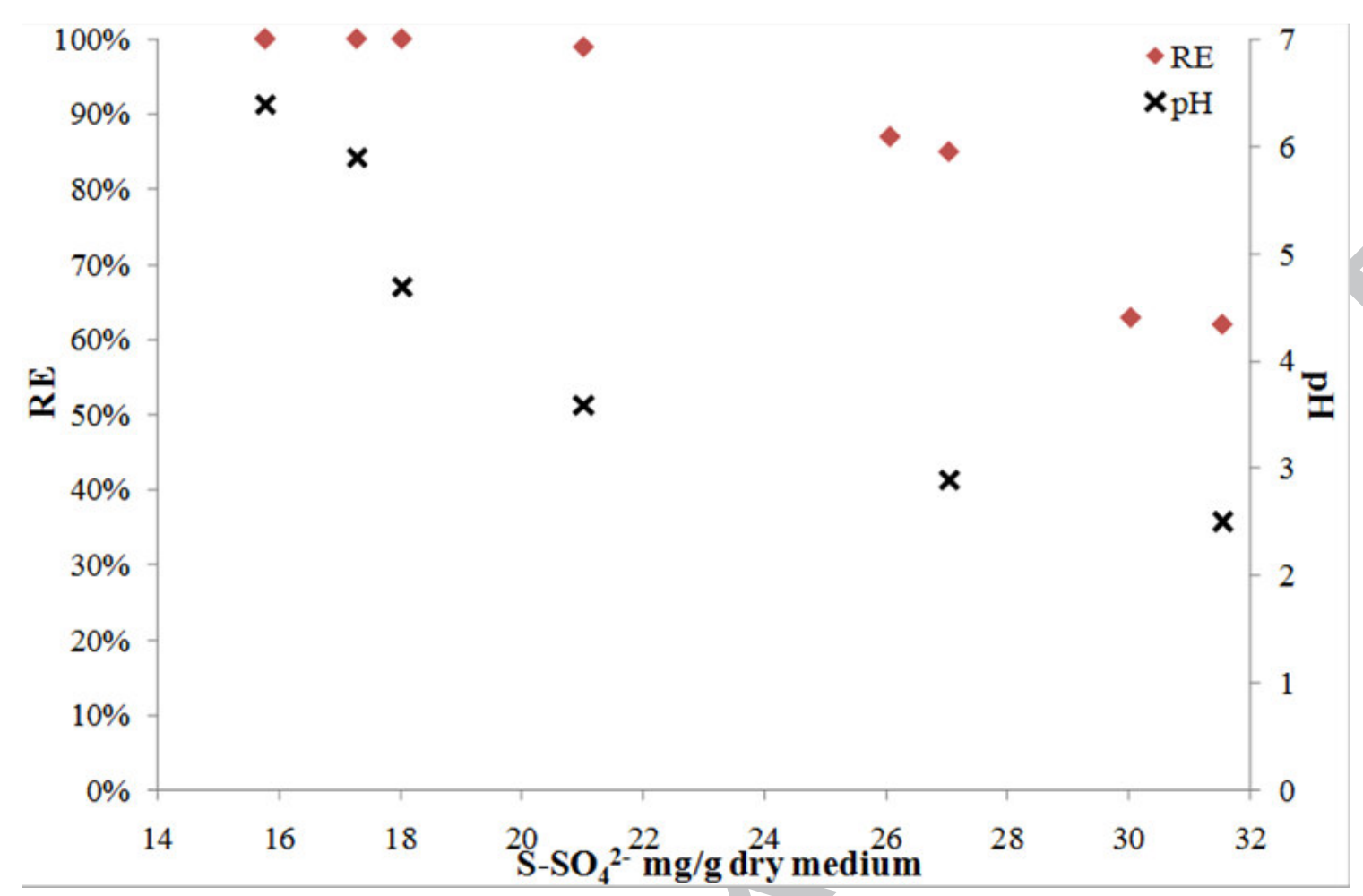




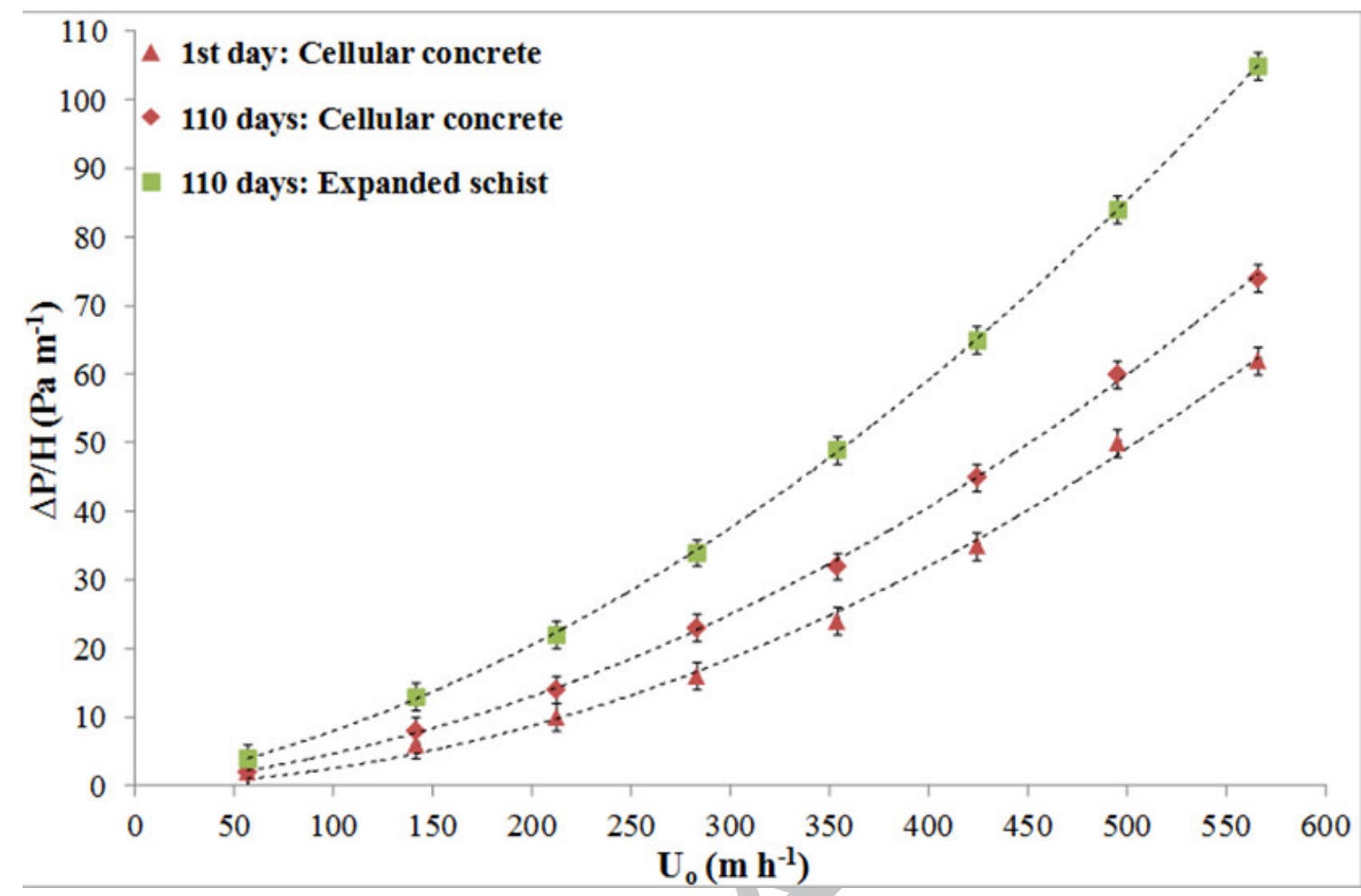




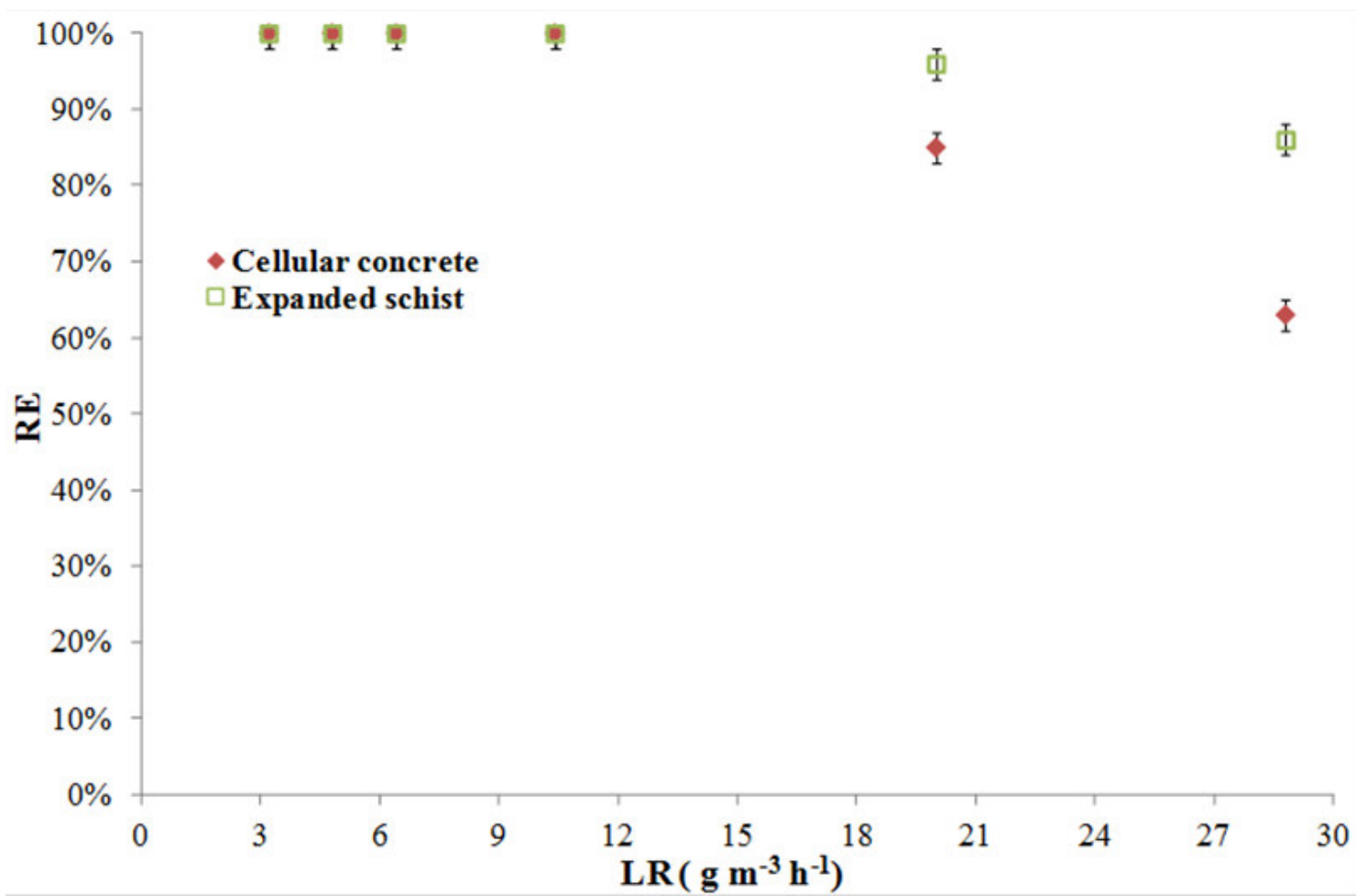



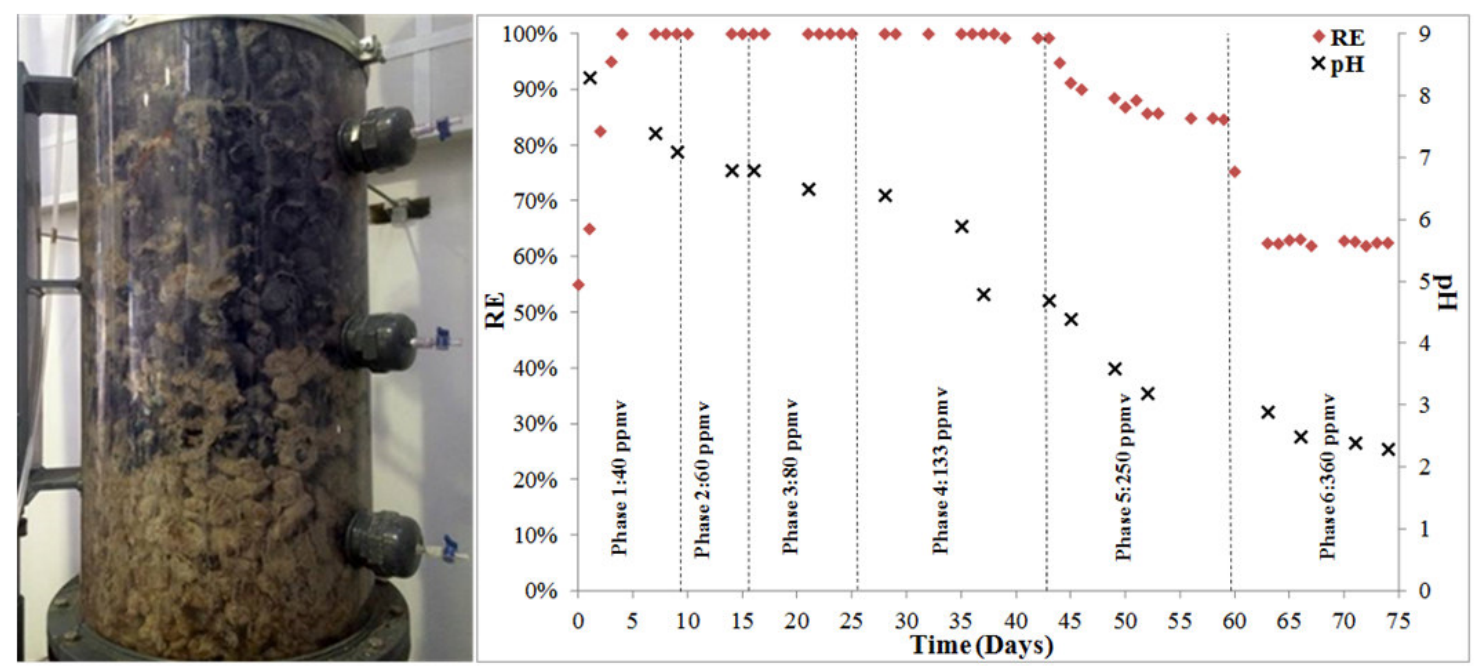

Graphical abstract 


\section{Highlights}

$\mathrm{H}_{2} \mathrm{~S}$ removal using cellular concrete waste was investigated

Cellular concrete is efficient for removing $\mathrm{H}_{2} \mathrm{~S}$ under dry conditions without biomass

Under abiotic conditions, each gram of concrete could remove at least $42 \mathrm{mg}$ of $\mathrm{H}_{2} \mathrm{~S}$

Cellular concrete waste is also efficient as a packing material for biofiltration

At $\mathrm{EBRT}=63 \mathrm{~s}$, the $\mathrm{EC}_{\max }$ of the biofilter was found to be $17.8 \mathrm{~g} \mathrm{~m}^{-3} \mathrm{~h}^{-1}$ 